\title{
Tutela da pessoa humana na lei geral de proteção de dados pessoais: entre a atribuição de direitos e a enunciação de remédios
}

\author{
Protection of the human person according to the general law of personal data \\ protection: between the attribution of rights and the enunciation of remedies
}

\author{
Eduardo Nunes de Souza* \\ Rodrigo da Guia Silva*
}

\section{Resumo}

A Lei n. ${ }^{\circ}$ 13.709/2018, conhecida como Lei Geral de Proteção de Dados Pessoais, ao instituir um sistema abrangente de proteção de dados pessoais no que diz respeito à coleta, circulação e tratamento desses dados, conta com um capítulo voltado especialmente à enunciação de "direitos". A análise detida de tais disposições, porém, revela que a lei enuncia (não exatamente direitos, mas sim) remédios voltados à tutela de direitos tradicionalmente reconhecidos pelo ordenamento brasileiro, em especial, a privacidade. A técnica remedial, mais comum em sistemas de common law, apresenta peculiaridades que merecem um estudo apurado, sobretudo no que diz respeito a não taxatividade desses instrumentos, de modo a possibilitar uma interpretação e aplicação mais adequada da nova lei. O presente estudo parte justamente da análise da técnica legislativa adotada e das diferenças entre direitos e remédios para situar as disposições da lei no contexto brasileiro e, assim, oferecer subsídios iniciais para o intérprete ao enfrentar o recente diploma legal.

Palavras-chave: Dados pessoais. Direitos. Remédios.

\section{Abstract}

Law n. 13.709/2018, known as the General Law for the Protection of Personal Data, in the attempt of establishing a comprehensive system for the protection of the holder of personal data with regard to the collection, circulation and processing of such data, offers a whole chapter specifically devoted to the enunciation of "rights". The analysis of these provisions, however, reveals that the law enunciates (not exactly rights, but rather) remedies aimed at protecting rights traditionally recognized by Brazilian law, especially the right to privacy. The technique of remedies, more usual in common law systems, has particularities that deserve a detailed study, especially with regard to the numerus apertus character of such instruments, in order to allow a more adequate interpretation and application of the new law. This study departs from the analysis of the adopted legislative technique and the differences between rights and remedies to situate the legal dispositions in the Brazilian context and, thus, to try and offer initial subsidies for the interpreter when facing the recent law.

Keywords: Personal data. Rights. Remedies.

\section{Introdução: direitos e remédios na LGPD}

$A^{1}$ edição de diplomas legislativos voltados à regulamentação abrangente de um inteiro setor econômico, ou à proteção de um grupo social específico, não corresponde a um fenômeno recente. Na experiência brasileira, a proliferação dos chamados estatutos se intensificou, particularmente, com a promulgação da Constituição de 1988, diante da necessidade que então se colocava ao legislador de implementar a

Doutor e Mestre em Direito Civil pela Universidade do Estado do Rio de Janeiro (UERJ). Professor Adjunto de Direito Civil da Faculdade de Direito da Universidade do Estado do Rio de Janeiro (UERJ). Rio de Janeiro - RJ - Brasil. E-mail: eduardo.souza@uerj.br.

Doutorando e mestre em Direito Civil pela Universidade do Estado do Rio de Janeiro (UERJ). Professor Substituto de Direito Civil da Faculdade Nacional de Direito da Universidade Federal do Rio de Janeiro (UFRJ). Advogado. Rio de Janeiro - RJ - Brasil. E-mail: rodrigo.daguiasilva@gmail. com.

Os autores agradecem, pelo auxílio na pesquisa, aos acadêmicos e bolsistas de iniciação científica Diego Bellot de Oliveira e Matheus Mendes de Moura. 
tutela proporcional e adequada determinada pelo constituinte a certos grupos de pessoas vulneráveis (os exemplos mais emblemáticos foram o Código de Defesa do Consumidor - CDC, o Estatuto da Criança e do Adolescente - ECA e, mais recentemente, o Estatuto do Idoso e o Estatuto da Pessoa com Deficiência EPD) (TEPEDINO, 2008, p. 8 e ss.; e BODIN DE MORAES, 2010b, p. 8 e ss.). Desde então, novas situações fáticas passaram a apresentar novos desafios à ordem jurídica brasileira (muitas vezes fomentadas pelo vertiginoso avanço tecnológico observado após a virada do século, a suscitar controvérsias concretas simplesmente impensáveis poucos anos antes). Dessas questões tem tratado, em geral, primeiramente a jurisprudência, à espera do naturalmente mais lento tratamento legislativo, o qual, por vezes, tarda a chegar e nem sempre atende, quando finalmente implementado, à expectativa social e às necessidades efetivas do setor então regulamentado.

Em matéria de dados pessoais, a atuação legislativa no Brasil tem sido fragmentada e bastante controvertida. Dentre as principais normas sobre o tema, vale destacar: a pioneira disciplina proposta pelo CDC aos bancos de dados e cadastros de consumidores (arts. 43-44); a Lei n. ${ }^{\circ} 12.527 / 2011$, que trata do acesso à informação em face de entes públicos, em regulamentação da garantia estabelecida pelo art. $5^{\circ}$, XXXIII, da Constituição Federal; a Lei n. ${ }^{\circ}$ 12.737/2012, muito criticada pela abordagem exclusivamente criminal de ilícitos cibernéticos, bem como por refletir uma resposta legislativa "de ocasião" (tendo o diploma ficado conhecido como Lei Carolina Dieckmann após caso de repercussão nacional envolvendo a atriz). Também, editada pouco tempo depois, a Lei n. ${ }^{0}$ 12.965/2014, que instituiu o Marco Civil da Internet, igualmente controverso, em particular pela proteção deficitária que seu art. 19 conferiu às vítimas de conteúdos lesivos postados por terceiros, visto que substituiu o sistema de notice and take down, que até então era aplicado pela jurisprudência em hipóteses semelhantes (SCHREIBER, 2015, passim; SOUZA, 2018, p. 52-53).

A edição da Lei Geral de Proteção de Dados Pessoais (LGPD - Lei n. ${ }^{\circ} 13.709 / 2018$ ), nesse cenário, acena em direção à já longeva demanda por um estatuto mais abrangente da matéria, capaz de conferir certa sistematicidade ao seu tratamento legislativo. ${ }^{2}$ Como ocorre com qualquer estatuto, porém, sua edição traz à tona o risco, há muito denunciado pela doutrina civil-constitucional, da interpretação fragmentária e setorial do diploma, na lógica dos muito aludidos microssistemas (PERLINGIERI, 2008, p. 209 e ss.; TEPEDINO, 2001, passim). Impõe-se, nesse sentido, compreender que, por um lado, as disposições contidas na LGPD se presumem corresponder à medida da tutela suficiente e adequada para os dados pessoais, conforme a ponderação democrática do legislador (não se admitindo a busca desordenada de dispositivos mais protetivos em outros diplomas normativos, na prática, por vezes - talvez equivocadamente -, designada como "diálogo de fontes") ${ }^{3}$; e que, por outro lado, em respeito ao caráter sistemático da ordem jurídica, cuja unidade se funda na tábua axiológica consagrada pela Lei Maior, a nova lei deve implementar e promover os valores do ordenamento (sob pena de se revelar inconstitucional), bem como ser interpretada de forma coerente com as demais normas e institutos do sistema.

Mais do que isso, a entrada em vigor de um novo estatuto, claramente voltado à tutela de uma particular vulnerabilidade do mundo contemporâneo (nomeadamente, a constante ameaça representada pelo avanço tecnológico aos dados sociais), suscita reflexões sobre o juízo valorativo efetuado pelo legislador ao atribuir expressamente certos direitos ao grupo vulnerável - os titulares de dados pessoais. Desse tema cuida um inteiro capítulo da LGPD (o Capítulo III - arts. 17 a 22), intitulado de forma inequívoca como "Dos Direitos do Titular". A análise das normas ali contidas, porém, como se buscará demonstrar, permite afirmar que as escolhas políticas refletidas na nova lei não se extinguem na atribuição de direitos, alcançando também a delicada calibragem do nível de tutela que o legislador pretendeu conferir a tais direitos. Nesse sentido, ao se deparar com um caso concreto e lançar seu primeiro olhar sobre a lei, não basta ao intérprete questionar: "O exercício da situação jurídica ora reconhecida é merecedor de tutela?". Impende que, ato contínuo,

\footnotetext{
"O ordenamento jurídico brasileiro já contava com algumas normas setoriais de proteção de dados (Código de Defesa do Consumidor - CDC, Lei do Cadastro Positivo e Marco Civil da Internet), mas não havia, ainda, uma lei aplicável horizontalmente a todos os setores econômicos e também ao setor público, como é o caso da LGPD". (DONEDA; MENDES, 2018a, item 2). Sobre o cenário legislativo brasileiro: Cf. Pinheiro (2019), Souza, Doneda, Nascimento e Guanaes (2018).

Para uma crítica a essa concepção, permita-se remeter a Souza, (2015c, p. 85-92).
} 
pergunte: "Qual é a exata medida da tutela conferida ao exercício da situação jurídica em exame?". A rigor, a decisão sobre o merecimento de tutela ${ }^{4}$ não se completa de sentido sem a delimitação da medida da tutela a que se faz jus no caso concreto (SILVA, 2019, item 1), e a disciplina prevista pela LGPD apenas destaca essa constatação.

A preocupação com a disponibilização de meios de tutela dos direitos parece se refletir na tradicional formulação segundo a qual a ordem jurídica atribuiria ao titular do direito diversas medidas destinadas à sua conservação ou defesa. A classificação dessas medidas variará de acordo com o critério de análise: quanto ao conteúdo, serão preventivas ou repressivas, conforme visem, respectivamente, a evitar ou reprimir uma lesão; quanto à forma de realização, serão judiciais ou extrajudiciais, conforme dependam ou não, respectivamente, da intervenção judicial (AMARAL, 2008, p. 247). O estudo dos chamados remédios, isto é, dos instrumentos voltados à tutela dos direitos, situa-se no âmago dessa discussão.

A maior parte dos estudos sobre o tema costuma se dedicar aos remédios que se voltam contra a lesão ou a ameaça às situações jurídicas subjetivas. ${ }^{5}$ Daí não se deve extrair, todavia, uma escusa para que o intérprete deixe de atentar também ao aspecto fisiológico do exercício das situações jurídicas, independentemente da instauração de uma lide, em particular quanto ao merecimento de tutela de certas formas de exercício pelo titular. ${ }^{6}$ Reduzir a análise ao aspecto patológico do exercício findaria por diminuir a importância da tutela assegurada pela ordem jurídica aos direitos (PERLINGIERI, 2011, p. 6-7). A investigação dos remédios assume, nessa direção, relevância central não apenas para se solucionarem hipóteses de perturbação (como a acepção coloquial da expressão remédio poderia levar a crer), mas também para se assegurar a efetividade do juízo positivo que o ordenamento faça recair sobre certo exercício de situações jurídicas. Assim, da indissociabilidade entre exercício e tutela dos direitos decorre a imprescindibilidade do estudo dos remédios, tanto para as manifestações fisiológicas de exercício quanto para as patológicas (SILVA, 2019, item 1).

Diante da particular escolha, efetuada pelo legislador da LGPD, de prever extenso rol de remédios voltados à tutela dos direitos por ele mencionados, um breve comentário acerca da relevância dos remédios na tradição romano-germânica mostra-se oportuna, após a qual será possível compreender, com maior precisão, o nível de proteção efetivamente conferido pela lei aos dados pessoais.

\section{Enunciação de direitos e atribuição de remédios a partir do esboço de uma comparação entre civil law e common law}

A doutrina usualmente converge, se não a propósito da definição precisa da expressão, ao menos no que tange à polissemia do termo remédio. Aponta-se, inicialmente, que a etimologia da palavra (remedium, do latim) (CUNHA, 2010, p. 555) remete à noção de cura ou reparo. ${ }^{7}$ Trata-se de noção amplamente difundida na doutrina especializada, em relevante coincidência com a acepção mais coloquial da expressão. ${ }^{8}$

4 Sobre a noção de merecimento de tutela, tanto em sua acepção ampla de juízo valorativo sobre exercícios privados quanto em seu possível sentido particular, cf. Souza (2014).

5 "Se todos os homens cumprissem espontaneamente seus deveres jurídicos, seria inútil a sanção que as normas de Direito contêm. Mas, se é certo que a maioria observa, 'por virtude, por disciplina, por hábito ou por temor', as regras jurídicas, não é pequeno o número de desobedientes. Para obrigá-los a comportamento conforme ao Direito, são proporcionados aos titulares de direitos os meios necessários para defendê-los. [...] A autodefesa e o direito de invocar a proteção jurídica do Estado são as duas modalidades principais de proteção. Outra modalidade de proteção é o nascimento automático de uma nova situação jurídica para eliminar a violação ou o perigo de lesão do direito" (GOMES, 2016, p. 393).

6 A destacar a relevância do aspecto fisiológico para a compreensão dos institutos jurídicos, sustenta-se a relevância de "[...] um critério metodológico fundamental [...], segundo o qual, para descobrir a essência de um instituto, é necessário referir-se às suas características fisiológicas e não já deixar-se atrair pelo seu eventual aspecto patológico" (BUSNELLI, 1964, p. 23. Tradução livre). A propósito da importância da análise do momento fisiológico, e não apenas do patológico, v., ainda, Perlingieri (2010, p. 27-28).

7 "A etimologia da palavra remédio, do latim remedium, remete a cura ou medicamento ou, em sentido figurado, a ajuda ou reparo" (MAZZAMUTO; PLAIA, 2012, p. 13. Tradução livre).

8 Colhem-se da lexicografia nacional as seguintes definições de remédio: "1. Aquilo que combate mal, dor ou doença. 2. Aquilo que serve para curar ou aliviar dor ou enfermidade. 3. Recurso, expediente, solução. 4. Ajuda, auxílio, socorro, proteção. 5. Correção, retificação, emenda" (FERREIRA, 2009 , p. 1.730). Digna de nota, ainda, a indicação da definição "jurídica" do vocábulo, mais consentânea com a proposição do presente estudo: "6. Meio adequado e lícito para se alcançar determinando fim de direito" (FERREIRA, 2009, p. 1.730). 
A polissemia é identificada também no âmbito da doutrina do common law, ${ }^{9}$ a qual se costuma atribuir relativo pioneirismo - em comparação com a doutrina do civil law - no próprio estudo técnico dos remédios ${ }^{10}$ Não causa espanto, assim, a consagração de expressões como "remedies for wrongs" ou "cure for wrongs" 11 para se fazer menção, entre outros aspectos, à problemática que a tradição romano-germânica designa como responsabilidade civil. ${ }^{12}$ Sem se ignorarem as divergências referentes à própria expressão "remedies for wrongs", ${ }^{13}$ o que se pretende destacar é que o longo período de desenvolvimento da matéria na tradição anglo-saxã não teve o condão de afastá-la da polissemia que a doutrina do civil law tem nela igualmente identificado (MESSINETTI, 2012, p. 103-105).

Afirma-se que os sistemas da família romano-germânica tradicionalmente dedicam grande atenção à enunciação e atribuição dos direitos, com particular destaque para a categoria do direito subjetivo. ${ }^{14} \mathrm{Tal}$ característica parece estar diretamente relacionada, ao menos, a dois pontos comumente identificados nesses sistemas: de um lado, à competência exclusiva (ou, ao menos, prioritária) do Poder Legislativo para a inovação na ordem jurídica, reservando-se ao Executivo e ao Judiciário funções cujo traço comum seria a execução das leis, mas não a sua criação ou alteração; ${ }^{15}$ de outro lado, à proeminência da lei como fonte do direito objetivo, ao que se associaria a histórica resistência (paulatinamente revisitada) ao reconhecimento de alguma relevante eficácia jurígena a fontes, como os costumes e a jurisprudência. ${ }^{16}$

No que diz respeito aos sistemas jurídicos da família anglo-saxã, de outra parte, historicamente se nega relevância à categoria do direito subjetivo e identifica-se a centralidade da atenção dispensada aos remédios. ${ }^{17}$ Nesse sentido, em oposição ao modelo de atribuição abstrata dos direitos pela lei, pautado por acentuado formalismo jurídico, prevaleceria a atribuição de remédios específicos pelo juiz em cada caso

Destaca-se, nesse sentido, a polissemia da expressão "remédio" na doutrina americana: "De resto, a confusão linguística e conceitual da noção é denunciada também pela literatura americana, a qual ressalta polemicamente a utilização poliédrica da expressão 'remédio', que induz a desperdiçar cada especificidade. [...] A heterogeneidade das exigências de proteção, especialmente se a caráter existencial, induziu a doutrina a elaborar uma categoria de medidas protetivas tão ampla a resultar em concreto de escassa utilidade" (PERLINGIERI, 2011, p. 7-8. Tradução livre). Para uma análise da referida polissemia nos sistemas do common law, v., ainda, Birks (2000, p. 3-6), Friedman (1992, p. 741 e ss.) e Laycock (2008, passim).

10 "....] na tradição do common law inglês a acepção é já técnico-jurídica e - como já se recordou precedentemente - a situação de necessidade ou de crise à qual se põe, precisamente, reparo é individualizada no torto (cure for wrongs). O remédio é, portanto, o instrumento para reparar a violação de um preceito e, então, se diferencia seja da norma atributiva de um direito seja da sanção". (MAZZAMUTO; PLAIA, 2012 , p. 13-14. Tradução livre).

11 Ao propósito, v., por todos, (MAJO, 2009, p. 3; MAZZAMUTO; PLAIA, 2012, p. 1).

12 Pertinente, ao propósito, a lição de Dário Moura Vicente sobre o desenvolvimento histórico da noção de tort no direito inglês: "Os writs delimitaram assim historicamente os tipos de ilícitos determinantes da obrigação de indenizar: os torts. Por tort entende-se um 'ilícito civil distinto da violação de um contrato' ('a civil wrong, other than a breach of contract'). Os torts só em parte correspondem, no entanto, aos delitos dos Direitos continentais, pois compreendem também certas situações, como o tort of trespass to land, que podem não dar lugar à obrigação de indenizar, mas antes fundamentar outro tipo de pretensões, como a manutenção ou a restituição da posse através de injunctions (correspondentes aos meios possessórios dos Direitos alemão e português)" (VICENTE, 2017, p. 399). Para uma análise da noção de tort no common law, v., ainda (Majo (2009, p. 51) e Harris, Campbell e Halson (2005, p. 289 e ss.).

13 A destacar que a usual conceituação de "remedy" como "cure for wrongs" não desfruta de aceitação pacífica, afirma-se: "Se o remédio como 'cure for wrongs' deixa perplexos os intérpretes, também as outras definições não satisfazem. Considerado sinônimo, volta e meia, de acionabilidade em juízo, de direito nascido de um ilícito (ou, de qualquer modo, de outras formas de injustiça), de provimento judicial (em geral ou somente de tipo discricionário), ou mesmo como 'qualquer coisa que uma corte pode fazer por quem sofreu um tort ou está por sofrê-lo' ('Anything a court can do for a litigant who has been wronged or is about to be wronged'), a pluralidade de significados do termo 'remedy' se reflete na vagueza das definições" (SMORTO, 2015, p. 197. Tradução livre).

14 "Historicamente, o civil law, em especial modo aquele de derivação germânica, põe ao centro do próprio quadro a consistência das situações jurídicas subjetivas através da teoria do direito subjetivo. Os ordenamentos da Europa continente confiam a individualização dos interesses tutelados - a denominada função atributiva - à relação entre direito subjetivo e ação" (SMORTO, 2015, p. 187. Tradução livre). V., ainda, NIVARRA, Luca. I nuovi orizzonti della responsabilità contrattuale. Torino: G. Giappiccheli, 2015, p. 18; e, do mesmo autor, NIVARRA, Luca. Rimedi: un nuovo ordine del discorso civilistico? Europa e Diritto Privato, n. 3, 2015, p. 601.

15 Cf., por todos, SMORTO, 2014, p. 182; e SMORTO, 2015, p. 188-189. Adverte-se, contudo: "Em qualquer destes sistemas jurídicos [romanogermânicos], as assembleias parlamentares são referidas como os órgãos legislativos por excelência, mas este corolário do princípio da separação de poderes vem sofrendo sucessivas atenuações. As regras e a prática constitucionais procedem na realidade a uma partilha do poder legislativo, em que a parcela pertencente aos Governos tem progressivamente aumentado [...]" (ALMEIDA; CARVALHO, 2017, p. 49). No mesmo sentido, Vicente, (2017, p. 154). Em defesa da importância da ressignificação da separação de poderes para o estudo do sistema remedial, cf. Friedman (1992, p. 770 e ss).

16 Para um desenvolvimento crítico da questão, v., por todos, Vicente (2017, p. 161 e ss.).

17 "Os ordenamentos de common law tradicionalmente não conhecem a ordem conceitual dos direitos subjetivos e organizam as próprias formas de tutela em torno da noção de remédio" (SMORTO, 2015, p. 189. Tradução livre). 
concreto, em busca da máxima efetividade ${ }^{18} \mathrm{O}$ ideal de efetividade da tutela jurisdicional não seria compatível com a enunciação abstrata dos direitos, razão pela qual se chega a afirmar que, nos países dessa família, a relevância da categoria do direito subjetivo se resumiria à indicação do grau de probabilidade da obtenção de um pronunciamento judicial favorável à parte. ${ }^{19} \mathrm{~A}$ centralidade dos remédios (remedies) relegaria a um papel secundário a atribuição formal de direitos (rights) ${ }^{20} \mathrm{ou}$, em formulação diversa, de posições jurídicas de vantagem (entitlements). ${ }^{21}$

As distinções antes apontadas poderiam ser sintetizadas pela oposição entre os brocardos que se costumam associar a cada uma das famílias de sistemas jurídicos: "ubi remedium ibi ius" versus "ubi ius ibi remedium" (SMORTO, 2015, p. 192). De uma parte, nos países de common law, o destaque da jurisprudência (ou, mais precisamente, dos precedentes) ${ }^{22}$ como fonte principal do direito e a centralidade da tutela judicial efetiva conduziriam ao reconhecimento de que "onde houver remédio, haverá direito". ${ }^{23}$ De outra parte, nos sistemas de civil law, a proeminência da lei como fonte do direito e a centralidade da enunciação e atribuição abstratas dos direitos conduziriam ao reconhecimento de que "onde houver direito, haverá remédio". ${ }^{24}$ Eis, em síntese, alguns dos principais contornos da diferenciação, concebida por parte da doutrina, entre a linguagem dos direitos (associada ao civil law) e a linguagem dos remédios (associada ao common law). ${ }^{25}$

A partir do quadro comparativo exposto, destacam-se, em sede doutrinária, questões supostamente relevantes para se ilustrarem as repercussões da diferenciação entre a linguagem dos direitos e a linguagem dos remédios. Uma primeira questão diz respeito à possibilidade ou não de reconhecimento, pelo juiz, de razões diversas daquelas que determinaram o reconhecimento de certo interesse como juridicamente protegido e a correlata atribuição de um direito (SMORTO, 2014, p. 174 e ss.). Afirma-se, a propósito, que o julgador, nos países de civil law, teria a responsabilidade de se manter fiel às escolhas valorativas

18 "Nestes sistemas a seleção dos interesses merecedores de tutela ocorre diretamente mediante a individualização das tutelas e não é necessário identificar uma posição subjetiva para que se possa dar resposta a um interesse lesado. A efetividade das tutelas prevalece sobre a enunciação abstrata dos direitos. Segundo um modelo de análise orientado aos remédios, de fato, para oferecer um quadro preciso e completo da consistência da proteção dos interesses é necessário verificar a efetividade das tutelas" (SMORTO, 2015, p. 190. Tradução livre).

19 "Nas suas expressões mais radicais, o discurso sobre os remédios sustenta que falar de direitos não signifique outra coisa que fazer predições sobre as futuras decisões judiciais. Nesta perspectiva, direito subjetivo se torna 'expressão linguística' através da qual se indica simplesmente outro grau de probabilidade de obter um juízo favorável, hipóstase de um argumento retórico dotado de um certo grau de idoneidade a persuadir quem tomará a decisão" (SMORTO, 2015, p. 190, nota de rodapé n. 14. Tradução livre).

20 Acerca da noção de right, remete-se, por todos, a Friedman (1992, passim; 2005, passim.).

21 Acerca da noção de entitlement, remete-se, por todos, a Calabresi e Melamed (1972, p. 1.090 e ss.). A propósito da centralidade dos remedies em detrimento dos rights e entitlements, afirma-se, ao se analisar a disciplina do enriquecimento sem causa no direito inglês: "O ponto central da análise é que um nível de atribuição (direito) [entitlement (right)] é substituído por outro (remédio) [remedy]" (BARKER, 1998, item IV. Tradução livre).

22 Refere-se, nesse sentido, aos ordenamentos do sistema do common law como "[...] ordenamentos em cuja base está o precedente judicial. Assim, por exemplo, embora atualmente seja frequente a referência a 'precedente', especialmente pelo STJ, não se trata da mesma coisa: o nosso precedente, necessariamente plural e relativo ao direito, denota, na verdade, o comportamento da 'jurisprudência', enquanto o 'precedente' em sua acepção original, de matriz anglo-americana, com frequência é único e refere-se aos fatos principais da demanda" (BODIN DE MORAES, 2013, p. 13-14). Para uma análise da centralidade dos precedentes nos sistemas do common law, v., ainda, Birks (1994, passim.).

23 Ao propósito, v., por todos, Friedmann (2005, p. 3-4); e Majo (2009, p. 4). Não por acaso, afirma-se que no sistema de common law a definição das posições jurídicas funcionaria como um posterius em relação à prévia individualização da tutela mediante remédios: "A lógica dos remédios, levada às suas consequências últimas, conduz a sustentar a irrelevância dos direitos: afirmar que existe um direito - se sustenta - é apenas um modo para dizer que o ordenamento concede um remédio, porque é apenas pelo remédio que é possível definir o interesse tutelado. Se realmente quisermos falar de direito, a definição das posições subjetivas de vantagem é, portanto, um posterius em relação à individualização dos remédios" (SMORTO, 2015, p. 191-192. Tradução livre).

24 Ao propósito, v., por todos, Friedmann (2005, p. 8 e ss.). Tal formulação parece estar associada ao desenvolvimento conferido pela doutrina ao debate acerca da relação entre direito e ação, como se depreende, por exemplo, das análises críticas de Majo (2009, p. 4); Mazzamuto e Plaia (2012, p. 1).

25 Vale destacar que a metodologia civil-constitucional chega a criticar, embora por fundamentos diversos, ambos os brocardos mencionados. De uma parte, a ideia de ubi remedium, ibi ius pecaria por antepor os remédios à própria definição dos interesses concretamente merecedores de tutela jurídica. De outra parte, a ideia de ubi ius, ibi remedium, embora adequada no que tange à anteposição dos interesses a serem tutelados face à individualização dos remédios, pecaria por sugerir que o reconhecimento dos interesses merecedores de tutela necessariamente haveria de conduzir à identificação de um remédio judicial. Nesse sentido se posiciona a crítica de Pietro Perlingieri (2011): "Não convence, antes de tudo, o assumido segundo o qual as necessidades de tutela são 'qualificadas' somente se reconduzíveis a interesses judicializáveis. [...] Assim, na passagem de uma dogmática dos direitos a uma dogmática dos remédios, o interesse assumiria relevância somente no momento patológico. Afirmar que a previsão de um remédio é medida da relevância jurídica de um interesse (ubi remedium ibi ius) não é operação lógico-jurídica diversa do afirmar que uma situação é merecedora de tutela somente se qualificada pelo ordenamento como direito (ubi ius ibi remedium)" (PERLINGIERI, 2011, p. 6-7). 
do legislador, ${ }^{26}$ ao passo que o julgador, nos sistemas de common law, não se apresentaria rigidamente comprometido com as razões tidas como relevantes pelo legislador, podendo, ao revés, reconhecer em cada caso posto à sua apreciação os interesses dignos de proteção, ainda que alheios às razões inspiradoras das previsões legais. ${ }^{27}$

Uma segunda questão diz respeito à discricionariedade do julgador, colocando-se em oposição um modelo de prevalência dos poderes ex ante do legislador em face de um modelo de prevalência dos poderes ex post do magistrado (SMORTO, 2014, p. 180 e ss.). A esse respeito, afirma-se que os sistemas da família romano-germânica imporiam ao julgador o dever de estrita observância dos preceitos legais, sem maiores possibilidades de manobra para a proteção efetiva de interesses ao arrepio da previsão legal. ${ }^{28}$ Nos sistemas da família anglo-saxã, diversamente, seria reconhecida ao magistrado uma expressiva esfera de discricionariedade para uma atuação criativa com vistas à atribuição de remédios efetivos aos interesses que se revelassem dignos de proteção em cada caso concreto. ${ }^{29}$

Uma terceira questão, ainda, refere-se à argumentação jurídica. Enuncia-se, a esse propósito, a prevalência de um modelo dito lógico-sistemático de interpretação nos sistemas de civil law, pelo reconhecimento de que, subjacente à dogmática do direito subjetivo, estaria o respeito à exclusividade do legislador para as definições e atribuições das posições jurídicas a serem protegidas. ${ }^{30}$ Prevaleceria nos sistemas de common law, por outro lado, um modelo dito teleológico, em que incumbiria ao julgador, mediante a atribuição concreta de remédios, a definição última dos interesses dignos de proteção.

A enunciação desses caracteres distintivos não impediu, contudo, que a própria doutrina, empenhada na diferenciação, ressalvasse a existência de uma expressiva similitude de resultados entre as referidas famílias de sistemas jurídicos ${ }^{31}$ Precisamente nesse sentido, já se sustentou que o civil law tenderia a se aproximar do common law a partir de construções teóricas que permitissem maior flexibilidade por parte do julgador na busca pela atribuição efetiva de remédios. ${ }^{32}$ Assim sucederia com o desenvolvimento, por exemplo, da boa-fé objetiva, da cláusula rebus sic stantibus, da teoria da pressuposição, da culpa in contrahendo, do abuso do direito e da exceptio doli generalis (SMORTO, 2015, p. 209-210).

Como se nota, embora reste clara a diferenciação abstrata entre civil law e common law, impõe-se reconhecer que muitos dos atributos acima mencionados sobre os sistemas da família romano-germânica podem não restar verificados na prática, a depender da metodologia adotada pelo intérprete. Por exemplo, há muito se afirma na doutrina do civil law a perda de centralidade da categoria do direito subjetivo. ${ }^{33}$ Com

26 Digna de nota a observação acerca da tendência à maior importância da jurisprudência no bojo dos sistemas romano-germânicos com códigos mais antigos, "[...] que os tribunais tiveram de adaptar a novas necessidades sociais" (VICENTE, 2017, p. 168).

27 "Adotando o léxico dos remédios, as tutelas às vezes 'replicam', outras vezes 'transformam', os direitos, e a escolha entre remédios que replicam e remédios que transformam direitos não depende da natureza do direito violado, mas de considerações de todo estranhas à conformação da posição subjetiva, de rationes novas e diversas daquelas relativas à atribuição da posição subjetiva" (SMORTO, 2014. Tradução livre).

28 Para uma análise crítica de tal atributo historicamente associado aos sistemas romano-germânicos, v. Sacco (2001, p. 93 e ss.).

29 "O common law reconhece, portanto, que as lógicas que presidem a administração da justiça ex post possam divergir daquelas que confluem na formulação da posição de vantagem e atribui ao juiz, no exercício da própria discricionariedade, a tarefa de colmatar essa distância. A linguagem dos remédios o reconhece e afirma que as tutelas às vezes 'replicam', outras vezes 'transformam'; outras, ainda, 'criam' os direitos" (SMORTO, 2015, p. 206. Tradução livre). V., ainda Lupoi (2009, .p. 177-178) e Perlingieri (2010b, p. 196).

30 Veja-se, ao propósito, a análise crítica de Perlingieri (2008, p. 674 e ss.).

31 "À distância entre as respectivas ordens conceituais corresponde, sobre o plano funcional, uma (parcial) identidade de perspectiva. Todos os ordenamentos, tanto de civil law quanto de common law, conhecem a exigência de uma redefinição dos interesses em jogo à luz do caso singular, são conscientes do fato de que o sopesamento dos interesses não se pode dizer de todo exaurido com a atribuição de propriedades normativas em abstrato e elaboram instrumentos voltados a fazer frente a essa exigência" (SMORTO, 2015, p. 202. Tradução livre).

32 "Também a jurisprudência de civil law sempre realizou, embora com sensibilidade e atenção variáveis, a tarefa de rever em sede aplicativa a consistência dos direitos subjetivos que o legislador havia definido na sua natureza absoluta (dura lex sed lex). Deste modo deu resposta à exigência de estender o próprio controle além dos estreitos limites da verificação de abstrata conformidade do exercício do direito à norma atributiva, e de verificar a legitimidade de comportamentos à luz do caso concreto, sem considerá-lo tais aprioristicamente pela abstrata conformidade ao direito conferido. A linguagem utilizada pelo legislador não pode mais que manter-se dentro de limites vagos e a regra finda por completar-se à luz das circunstâncias do caso concreto, segundo cânones hermenêuticos que não se exaurem na mecânica aplicação do ditado normativo postulada pela tradicional dicotomia direito/ação" (SMORTO, 2014, p. 178. Tradução livre).

33 "O direito subjetivo - figura controvertida desde sempre - perde centralidade definitivamente e aflui a exigência de diversificar os interesses e de dar formas e técnicas de tutela das pessoas asseguradas por novos órgãos e por novos instrumentos, individualizados segundo o tipo de interesse a ser tutelado e a ponderação de valores a ser realizada" (PERLINGIERI, 2008, p. 678). Digna de nota a lição de Mazzamuto e Plaia (2012, p. 3. Tradução livre): "O percurso marcado pela precedência do remédio em relação ao direito é um traço característico dos sistemas de common law caracterizados pela cristalização dos direitos em torno dos remédios, mas não pode ser considerado estranho aos sistemas de civil law". 
efeito, reconhece-se, cada vez mais, que as relações jurídicas traduzem uma vasta diversidade de situações jurídicas, para além dos limites conceituais do direito subjetivo (SOUZA, 2015d, passim), modelo insuficiente para explicar a complexidade relacional (SOUZA, 2017, p. 114 e ss.). Destaca-se, ademais, a impropriedade da adoção do direito subjetivo para a compreensão e a tutela das relações existenciais (PERLINGIERI, 2005, p. 14 e ss.; TEPEDINO, 2004, passim; BODIN DE MORAES, 2010b, item 2).

Também a suposta prevalência da enunciação abstrata dos direitos em detrimento da efetividade da tutela jurisdicional concreta parece não corresponder necessariamente ao modo pelo qual se pode enxergar um sistema jurídico do civil law. ${ }^{34}$ Nesse sentido, tem crescido a defesa da impossibilidade de uma completa atividade hermenêutica sem a consideração dos valores tangenciados por cada caso concreto. ${ }^{35}$ A expressividade de tal tendência se manifesta, em ocorrência emblemática, na construção doutrinária que critica a própria distinção estanque e abstrata entre as duas famílias de sistemas jurídicos a partir dos brocardos "ubi jus, ibi remedium" e "ubi remedium, ibi jus".

De uma parte, destaca-se que não raramente os remédios encontram fundamento direto em textos legislativos; de outra parte, a atribuição de um remédio em um sistema do common law se justifica em função da tutela de um interesse cuja juridicidade tenha sido reconhecida a partir da análise do ordenamento (reconhecida, por certo, a primazia que cada sistema conferir internamente às possíveis fontes do direito). ${ }^{36}$ Percebe-se, em suma, o risco na exasperação da dicotomia: tanto é verdade que o direito justificador de remédios nos sistemas do civil law não se resume à categoria do direito subjetivo quanto parece improvável, do ponto de vista lógico-jurídico, que a atribuição de um remédio pela autoridade estatal nos sistemas do common law possa se operar sem que se identifique um interesse reputado merecedor de proteção pela ordem jurídica (SILVA, 2019, item 3).

Por fim, de melhor sorte não desfruta a enunciação segundo a qual o modelo do civil law aprisionaria o magistrado nos limites rígidos da legislação ordinária ${ }^{37}$ e da técnica subsuntiva. ${ }^{38}$ Compreende-se, de fato, a atual insuficiência da técnica da subsunção (SOUZA, 2014, p. 79 e ss.; SILVA, 2017b, p. 53), identificando-se, no cenário contemporâneo, ao revés, uma "reconstrução do Direito a partir de princípios - que representam valores estabelecidos na Constituição" (BODIN DE MORAES, 2013, p. 19). Desse modo, em superação do monopólio do pensamento subsuntivo, destaca-se a importância central da ponderação, técnica idônea a promover o sopesamento de todas as normas (e, sobretudo, dos princípios) para a solução de cada caso concreto (PERLINGIERI, 2015, p. 68). Liberta-se o intérprete dos limites estreitos da lei ordinária, ${ }^{39}$

34 Perlingieri (2010) destaca: "É impossível, portanto, construir uma teoria das fontes sem interpretação. A teoria da interpretação é parte integrante da teoria das fontes e é inconcebível que a primeira seja exaurida na individuação do significado do dado literal. O direito tem por objeto fatos concretos. Objeto da interpretação não é a norma, mas sim a norma unida ao fato. É necessário ter a força intelectual e cultural de recuperar a normatividade da factualidade, a valência normativa dos fatos, o que implica que a hermenêutica jurídica não se possa exaurir em uma ciência da linguagem" (PERLINGIERI, 2010a, p. 27. Tradução livre). Justifica-se, portanto, a cautela para com as formulações que apontem uma suposta menor importância do dado fático para a interpretação no civil law: "As distâncias entre civil law e common law permanecem tantas e significativas. O common law reconhece de modo mais claro a exigência de uma análise que leve em consideração tanto a posição subjetiva reconhecida em abstrato quanto o remédio concedido em concreto, e sobretudo a relativa independência das duas questões" (SMORTO, 2015, p. 204. Tradução livre).

35 "Longe de aderir a lógicas formalistas, a busca pela medida mais adequada deve concentrar-se sobre o interesse juridicamente relevante: é necessário, em suma, privilegiar não a declamação dos direitos, mas a efetividade das soluções concretamente oferecidas pelo ordenamento diante da violação a um específico interesse" (PERLINGIERI, 2011, p. 4. Tradução livre). No mesmo sentido, cf. Smorto (2015, p. 203).

36 Eis a lição de Luca Nivarra: "Francamente, não posso dizer se simplificações deste gênero são confiáveis, e em que medida. De qualquer modo, gostaria de salientar que: (i) os remédios de que se fala encontram a própria fonte nos textos do direito comunitário derivado que, embora questionáveis sob o perfil da técnica redacional, são textos legislativos e, portanto, colocam no sistema enunciados muito mais gerais e abstratos do que individuais e concretos; (ii) os 'remédios' de que se fala remontam a um interesse cuja juridicidade já foi afirmada por uma norma diversa daquela atributiva do remédio" (NIVARRA, 2015a, p. 19-20. Tradução livre). Cf., ainda, Nivarra (2015b, p. 602-603).

37 "É verdade, porém, que o argumento orientado às consequências teve historicamente pouco espaço no civil law, em que a atividade hermenêutica do juiz sempre foi concebida como o produto da interpretação de normas de decisão formuladas de modo condicional e aplicadas mecanicamente ao caso concreto por parte do juiz" (SMORTO, 2014, p. 187. Tradução livre).

38 A ilustrar a formulação doutrinária de uma associação (indevida, vale frisar) entre o civil law e a técnica da subsunção, chega-se a se afirmar que a superação desse (suposto) paradigma representaria um "acolhimento ao menos parcial daquela arraigada flexibilidade própria do plano dos remédios" (SMORTO, 2014, p. 179-180. Tradução livre).

39 Tal tendência é destacada pela doutrina que se ocupa de analisar o maior espaço de criatividade (sempre reconduzida à legalidade constitucional e sujeita à fundamentação detida) atribuído ao julgador pelas cláusulas gerais (CASTRONOVO, 1986, passim; MAJO, 1984, p. 545-552). Para uma análise mais detida acerca da expansão dessa técnica legislativa, embora sem superação absoluta da técnica regulamentar, cf., por todos, Rodotà (1987, passim.). 
impondo-se a ele, por outro lado, a contrapartida de demonstrar fundamentadamente a compatibilidade de cada decisão (e do respectivo processo argumentativo) com a tábua axiológica constitucional. ${ }^{40}$

\section{Releitura da pretensa atribuição de direitos ao titular de dados pela LGPD a partir de um prisma remedial}

Como referido anteriormente, o regime inaugurado pela LGPD dispensa capítulo próprio à enunciação dos "direitos do titular" de dados pessoais. O uso do termo "titular", embora criticado por parte da doutrina (que identifica na referência à titularidade uma remissão à ótica proprietária, de todo inadequada em matérias que dizem respeito diretamente à pessoa humana), ${ }^{41}$ parece ainda oportuno, tendo em vista a necessidade de identificar com clareza os sujeitos a que se refere a lei. A rigor, considerando que a titularidade consiste no vínculo que une o indivíduo a toda situação jurídica, de qualquer natureza (patrimonial ou existencial), o uso do termo em matéria extrapatrimonial mostra-se tão adequado quanto a referência a situações jurídicas nesse setor (e a lei, neste particular, remete claramente à estipulação de direitos).

Nos termos do art. 17 da lei, "toda pessoa natural tem assegurada a titularidade de seus dados pessoais e garantidos os direitos fundamentais de liberdade, de intimidade e de privacidade, nos termos desta Lei". ${ }^{42}$ Trata-se de rol pouco inovador de direitos,$^{43}$ os quais foram inseridos no elenco de direitos fundamentais da Constituição Federal (art. $5^{\circ}$, caput e inciso X) e já decorreriam, segundo entendimento bastante consolidado, da própria cláusula geral de tutela da pessoa humana (art. $1^{\circ}$, III da CF) (BODIN DE MORAES, 2010b, p. 125 e ss.; e TEPEDINO, 2004, p. 50 e ss.). Com efeito, há muito já se destaca na doutrina civil-constitucional a desnecessidade da enunciação legislativa dos chamados direitos da personalidade, isto é, de direitos existenciais típicos, visto que todo e qualquer interesse decorrente da dignidade humana há de ser tutelado (sem dúvida, em ponderação com eventuais outros interesses contrapostos), independentemente de sua enunciação na forma de situações jurídicas específicas (KONDER, 2018, p. 2-3).

Dos três direitos citados pelo dispositivo em questão, o mais inusitado (diante da abertura excessiva de seu conteúdo) é o de "liberdade"; com efeito, a autonomia está no cerne de todas as questões atinentes às relações privadas (ainda que contemporaneamente funcionalizada a interesses de ordem supraindividual, como os vinculados à solidariedade social). Já no que tange às relações entre indivíduo e Estado, as liberdades civis consistem nos direitos fundamentais há mais tempo reconhecidos, ditos de primeira geração, o que faz parecer despicienda sua remissão legislativa, exceto para a finalidade de afirmar o norte valorativo que o legislador tinha em mente quando da elaboração da lei.

No que diz respeito à intimidade, sua distinção em relação à privacidade mostra-se cada vez mais incomum, sendo os termos utilizados contemporaneamente como sinônimos (PEREIRA, 2011, p. 217). Na doutrina tradicional, em que se conferia grande importância à gradação entre a esfera privada e a pública, a intimidade representava o âmbito mais reservado da vida individual, um espaço frequentado apenas pela própria pessoa, ao passo que a privacidade correspondia a uma proteção mais ampla, referente à relação do indivíduo com o mundo e sua prerrogativa de não ser importunado com o acesso indevido de terceiros a fatos de sua vida quotidiana. ${ }^{44}$ Justamente por sua definição mais abrangente, a privacidade costuma responder, contemporaneamente, também pelas noções de intimidade e vida privada. A esse respeito,

40 "Daí o papel essencial que assume, sob o paradigma pós-positivista, a argumentação. O recurso aos princípios deflagra hipóteses em que dois princípios, ambos válidos e legítimos, entram em colisão ao oferecerem soluções opostas ao caso concreto: nessas hipóteses, a aplicação do Direito impõe o recurso à chamada ponderação, para encontrar qual deles é o mais adequado àquele caso, qual tem sua aplicação mais justificada. Este procedimento é essencialmente argumentativo e vem inspirado pela construção de uma teoria da argumentação, calcada na existência de uma lógica informal, que se aparta da racionalidade matemática, sem abrir mão dos processos de verificação de razoabilidade que lhe garantem legitimidade" (BODIN DE MORAES, 2013, p. 19-20).

41 Sobre a inadequação da lógica proprietária nesse setor, cf. Rodotà (2008, p. 98 e ss.).

42 Para uma análise crítica - de que não se partilha - do enfoque da LGPD sobre a tutela da pessoa humana (aspecto explicitado, entre tantos outros, pelos arts. $1^{\circ}$ e 17$)$, v. Magalhães e Divino (2018, p. 40 e ss.).

43 Afirma-se, em comentário ao art. 17 da LGPD: "Trata-se de artigo que, na verdade, apenas repete vários dos direitos anteriormente já mencionados, com a desvantagem de não se referir expressamente a todos" (FRAZÃO, 2018).

44 "A este período remonta o paradigma da privacidade como uma zero-relationship, como a ausência de comunicação entre um sujeito e os demais" (DONEDA, 2006, p. 8-9). 
já se identificou uma "inclusão progressiva de novos aspectos de liberdade num conceito ampliado de privacidade". ${ }^{45}$ (RODOTÀ, 2008, p.15).

A própria concepção de privacidade, como se sabe, passou por relevante ressignificação nas últimas décadas, sendo hoje associada à noção de autodeterminação informativa. Vale aludir, nesse ponto, à célebre lição de Stefano Rodotà (2008, p.15), para quem a privacidade, em sua acepção mais contemporânea, deve ser compreendida também como o "direito de manter o controle sobre suas próprias informações e de determinar a maneira de construir sua própria esfera particular". ${ }^{46}$ Não é difícil compreender, nesse sentido, por que a privacidade assume particular protagonismo em um diploma legislativo voltado à proteção de dados pessoais - embora, reafirme-se, sua previsão pelo legislador ordinário, dada a consagração do direito pela própria Constituição, revela mais uma declaração de intenções da LGPD (papel que já é desempenhado, de modo mais técnico, pelo art. $2^{\circ}$ da lei) do que uma mudança efetiva na atribuição de direitos à pessoa humana.

Seria de se esperar que os dispositivos normativos previstos, em seguida, pela LGPD, ultrapassada a previsão (por assim dizer, panorâmica) do art. 17, tratassem da atribuição de efetivos novos direitos aos titulares de dados pessoais, desta vez voltados de modo mais específico aos problemas postos pelas fattispecie disciplinadas pela lei. As disposições dos arts. 18 e ss., no entanto, contrariando tal expectativa (criada, antes de tudo, pela designação conferida ao Capítulo III), tratam, predominantemente, de questões procedimentais ou instrumentais. ${ }^{47}$ Ilustrativamente, no que diz respeito ao art. 18 , cuida ele do "direito" do titular de obter do controlador a confirmação da existência de tratamento dos seus dados, o acesso a esses dados, a possibilidade de correção ou atualização dos mesmos, bem como de anonimização, bloqueio ou eliminação de dados desnecessários ou tratados de forma incorreta, dentre outros possíveis requerimentos.

Como se percebe, tais prerrogativas nada mais representam do que especificações do conteúdo que tradicionalmente se atribui à noção contemporânea de privacidade. De fato, a concepção de autodeterminação informativa, pela sua própria designação, converte a privacidade, em larga medida, no direito atribuído a cada pessoa de controlar a circulação dos seus próprios dados, por meio de uma série de medidas e procedimentos. Em outros termos, trata-se, precipuamente, do balizamento, pelo titular, do tratamento de seus dados por terceiros, e não propriamente da mera preservação desses dados contra o conhecimento público (como no conceito tradicional de privacidade). Esse sentido contemporâneo de privacidade, segundo a mais autorizada doutrina (RODOTÀ, 2008, p. 60 e ss.; DONEDA, 2006, p. 216-217), implementa-se por meio de garantias reconhecidas há décadas, dentre as quais são normalmente mencionadas:

i) Correção na coleta e no tratamento das informações: questão abordada prioritariamente em outros setores da lei, como aqueles que preveem a possibilidade da imposição de medidas corretivas aos agentes de tratamento de dados (art. 52 , I e $\left.\S 1^{\circ}, X\right)$;

ii) Segurança física e lógica da coletânea dos dados: garantia de que trata o Capítulo VII da LGPD (DONEDA; MENDES, 2018b, item 2);

iii) Publicidade dos bancos de dados pessoais: exigência que se reflete, por exemplo, no dever dos agentes de tratamento de dados de confirmarem a existência do tratamento (art. 18, I) e no dever de informação das entidades públicas e privadas com as quais o controlador realizou uso compartilhado de dados (art. 18, VII);

\footnotetext{
5 E também em relação a outros chamados direitos da personalidade tem-se observado certa absorção pela noção de privacidade. Assim se sustentou a respeito da honra em Souza (2015c, p. 307 e ss.). Já no que diz respeito à imagem, Bruno Lewicki (2008, p. 111) faz referência à "vocação expansiva de um conceito cada vez mais inseparável do direito à própria imagem".

46 Para um relato da difusão da referida linha de entendimento no direito brasileiro, v. Mulholland (2018, p. 171 e ss.).

47 Aponta-se, por exemplo, o caráter procedimental dos parágrafos do art. 18 da LGPD: “Já o inciso VIII pode ser considerado uma especificação do direito à informação, diante da importância do consentimento do titular como regra geral para a utilização dos seus dados pessoais. Daí mencionar o direito à 'informação sobre a possibilidade de não fornecer consentimento e sobre as consequências da negativa'. Com efeito, apenas se pode cogitar de consentimento inequívoco do titular de dados se ele souber as repercussões tanto da sua aceitação como da sua recusa" (FRAZÃO, 2018).
} 
iv) Acesso aos dados pessoais, diretamente acionável pelo titular interessado: expressamente aludido pelo inciso II do art. 18, além de referenciado como princípio orientador das atividades de tratamento de dados pessoais pelo art. $6^{\circ}$, IV;

v) Exatidão dos dados coletados e obrigatoriedade de sua atualização: essa garantia se efetiva, dentre outros instrumentos, pela prerrogativa, prevista no inciso III do supramencionado art. 18, de correção de dados incompletos, inexatos ou desatualizados, a pedido do titular, e é reforçada pela norma do $\$ 6^{\circ}$ do mesmo dispositivo, que determina ao agente que recebe o pedido de retificação, atualização ou supressão de dados que informe imediatamente a outros agentes com os quais tenha realizado o uso compartilhado dessas informações, para que eles possam repetir o mesmo procedimento, sem que se imponha ao titular a (muitas vezes impossível) tarefa de rastrear todos os agentes com os quais seus dados tenham sido compartilhados;

vi) Respeito à finalidade para a qual os dados foram coletados e tratados: enunciada no rol de princípios do art. $6^{\circ}$ (inciso I), essa garantia pode ser compreendida tanto como a pertinência entre a finalidade perseguida e os dados colhidos como a própria especificação da finalidade (vedando-se o uso abusivo dos dados em outras hipóteses). ${ }^{48}$ Segundo alguns autores, aqui também estaria compreendido 0 direito ao esquecimento (SCHREIBER, 2014, p. 172-174).

Dada a deliberada abertura conceitual dessas garantias (não por acaso frequentemente denominadas princípios), são frequentes as interpenetrações entre elas. Afirma-se, por exemplo, que o "direito" de acesso abrange a prerrogativa de revisão, retificação, atualização e supressão dos dados pessoais. ${ }^{49}$ Sustenta-se, ainda, que o livre acesso, que por muito tempo esteve em posição de proeminência na tutela dos dados pessoais, cede cada vez mais espaço ao princípio da finalidade, diante da necessidade de controle dos propósitos a que se presta a elaboração de certos bancos de dados, especialmente aqueles voltados à construção de perfis pessoais (RODOTÀ, 2008, p. 104). A enumeração dessas garantias, de todo modo, contribui para a atividade hermenêutica à medida que ajuda a exemplificar o conteúdo do princípio da privacidade. Ademais, tais garantias representam pontos de certo consenso em uma longeva tradição da disciplina jurídica dos dados pessoais, ao menos no sistema continental, ${ }^{50}$ remontando a documentos internacionais, como a Convenção do Conselho da Europa, de 28 de janeiro de 1981, e à Recomendação da Organização para a Cooperação e Desenvolvimento Econômicos (OCDE), de 23 de setembro de 1980.

A leitura dos incisos do art. 18, nesse sentido, permite inferir que a LGPD não inova na atribuição de direitos ao titular de dados pessoais, visto que apenas reproduz conteúdos que já eram atribuídos de longa data ao direito à privacidade. Em vez disso, consagra medidas e procedimentos que podem ser adotados pelo titular de dados ou que devem ser implementados pelo agente de tratamento, com vistas a efetivar a tutela da privacidade e, mais do que isso, mensurar a extensão da tutela desse direito. ${ }^{51}$ Trata-se, na perspectiva antes exposta, da previsão de remédios para a tutela da privacidade - os quais, como visto, voltam-se não apenas a sanar violações como, igualmente, a prevenir lesões e viabilizar o próprio exercício do direito. A privacidade, neste ponto, mostra-se particularmente exemplar para o estudo dos remédios, já que seu conteúdo contemporâneo tem sido deliberadamente referido como um conjunto de medidas e

48 Com base no princípio da finalidade, "fundamenta-se a restrição da transferência de dados pessoais a terceiros, além do que é possível a estipulação de um critério para valorizar a razoabilidade da utilização de determinados dados para certa finalidade (fora da qual haveria abusividade)" (DONEDA, 2006, p. 216). V., ainda, Doneda e Mendes (2018b, item 2)

49 Exatamente nessa linha de sentido, Stefano Rodotà (2008) alude ao caráter instrumental do princípio de acesso (nominalmente tratado como direito de acesso pelo art. 18, III, da LGPD): "Bem diversa é a situação do princípio de acesso. Este é, antes de tudo, um instrumento diretamente acionável pelos interessados, que podem utilizá-lo não somente com a finalidade de simples conhecimento, mas também para promover propriamente a efetividade de outros princípios. Saliente-se, de fato, que entre os poderes atribuídos pelo direito de acesso existe também o de obter a correção, a integração ou a eliminação dos dados coletados" (RODOTÀ, 2008, p. 60). No direito brasileiro, cf. Doneda (2006, p. 217).

50 Conforme anota Danilo Doneda (2006, p. 217): "Estes princípios, mesmo que fracionados, condensados ou então adaptados, podem ser identificados em diversas leis, tratados, convenções ou acordos entre privados. Eles são o núcleo das questões com as quais todo ordenamento deve se deparar ao procurar fornecer sua própria solução ao problema da proteção dos dados pessoais".

51 Emblemática, nessa linha de sentido, a associação esquemática, proposta por Ana Frazão, entre os direitos dos titulares de dados e os princípios dos quais aqueles decorreriam (FRAZ̃̃O, 2018b). 
procedimentos (voltados ao acesso e ao controle de finalidade do tratamento de dados), atuantes, em sua maior parte, independentemente da existência de uma violação. ${ }^{52}$

A principal diferença em relação à definição mais tradicional de remédios, evidentemente, reside no fato de que, à diferença do que ocorre na experiência do common law, no caso da LGPD os remédios são previstos em abstrato pelo legislador, e não demarcados concretamente pelo juiz. Em princípio, nada mais natural, já que, a despeito do protagonismo assumido pela atividade judicante no direito brasileiro (não isento de muitas críticas, as quais transbordariam o escopo deste estudo), a lei remanesce como a fonte primária do Direito no sistema pátrio. O risco na enumeração legislativa de remédios em um país de civil law, porém, reside justamente em se tratar de procedimento ainda pouco compreendido pela cultura jurídica dessa família, mais habituada à enumeração de direitos - e, de fato, o próprio legislador denomina como "direitos" os instrumentos por ele concebidos.

O inconveniente na confusão entre remédios e direitos está no risco de difusão de uma concepção segundo a qual mecanismos eminentemente instrumentais, voltados a viabilizar a tutela de direitos e a mensurar a extensão dessa tutela, seriam situações jurídicas subjetivas próprias, autônomas e merecedoras de tutela per se. Nesse sentido, poder-se-ia supor, equivocadamente, que "direitos", como o de livre acesso aos dados pessoais pelo titular, corresponderiam a um fim em si mesmo, interesses particulares aos quais o ordenamento confere exigibilidade jurídica após um juízo valorativo prévio (como se presume a partir do reconhecimento de qualquer situação jurídica subjetiva dita "ativa"). ${ }^{53}$ Ao contrário, a ancoragem das medidas e procedimentos previstos no rol do art. 18 ao direito de privacidade (vale dizer, sua instrumentalização a esse direito) mostra-se imprescindível, pois é o direito que, traduzindo valores e interesses, é passível de um juízo de merecimento de tutela. Em outros termos, é possível funcionalizar direitos à axiologia do sistema, mas não remédios legais isoladamente considerados. Estes, se dissociados do direito que se voltam a tutelar, tornam-se estruturas vazias de conteúdo - daí decorrendo o risco de serem interpretados como prerrogativas absolutas.

Nesse sentido, como se vem de afirmar, a doutrina destaca que o exercício concreto do "direito" de acesso (inclusive da prerrogativa de obter a correção, integração ou eliminação dos dados coletados) "pressupõe a violação de outro princípio, por exemplo, o da correção, da exatidão ou da finalidade: o princípio do acesso coloca-se, portanto, em um plano diferente e surge como um instrumento para a atuação direta de um interesse individual e para garantir a efetividade de um (outro) princípio geral" (RODOTÀ, 2008, p. 60). Por sua vez, a violação desses outros princípios, notadamente o da finalidade, há de ser aferida com referência ao valor da privacidade, a qual, a seu turno, encontra-se naturalmente funcionalizada à dignidade humana. Esse imprescindível encadeamento - eminentemente dialético - de valores, com diversos graus de especificidade, é fundamental para que se possa aferir o merecimento de tutela do exercício dos remédios previstos pela LGPD.

Esta parece ser também a chave de leitura mais adequada para os deveres de informação previstos em lei, em geral, e especificamente aquele decorrente da previsão do inciso VIII do art. 18, que assegura ao titular de dados o direito a obter do controlador "informação sobre a possibilidade de não fornecer consentimento e sobre as consequências da negativa". ${ }^{44} \mathrm{Com}$ efeito, tal dever apenas se justifica quando se compreende que alguns dos principais óbices à efetividade do livre acesso, há muito denunciados em doutrina, eram a falta de informação acerca das prerrogativas e procedimentos abertos ao titular de dados,

52 "Desta forma verifica-se a passagem de uma enunciação negativa e passiva da proteção dos dados para uma positiva e dinâmica. A técnica jurídica utilizada não é mais a da atribuição ao sujeito privado de um direito acionável diante de um órgão ad hoc somente depois da sua violação. Agora é concedido ao privado um poder de controle direto e contínuo sobre os coletores de informações, independentemente da existência real de uma violação. Muda assim a técnica de proteção da privacidade e a atenção se desloca para o bom funcionamento das regras sobre a circulação das informações" (RODOTÀ, 2008, p. 60).

53 Como afirma Pietro Perlingieri (2008, p. 669), o interesse "é o fundamento justificador da situação". Para um desenvolvimento do estudo das situações jurídicas subjetivas, remete-se a Souza (2015d, passim.).

54 Em comentário ao inciso VIII do art. 18 da LGPD, afirma-se: "Já o inciso VIII pode ser considerado uma especificação do direito à informação, diante da importância do consentimento do titular como regra geral para a utilização dos seus dados pessoais. [...] Com efeito, apenas se pode cogitar de consentimento inequívoco do titular de dados se ele souber as repercussões tanto da sua aceitação como da sua recusa" (FRAZÃO, 2018a). 
bem como o excesso de burocracia envolvida (RODOTÀ, 2008, p. 68). Buscar o direito ao qual se volta o remédio, e os valores e interesses aos quais o direito se encontra funcionalizado, permite compreender a extensão e os limites deste e de tantos outros deveres de informação com fonte legal: assim, por exemplo, o dever de informação no contrato de seguro deve ser aquele necessário à correta delimitação do risco, ${ }^{55}$ os deveres de informação decorrentes da boa-fé objetiva devem ser aqueles necessários para garantir a utilidade das prestações buscadas pelas partes (aferida a partir da noção de causa contratual) ${ }^{56}$ e assim por diante.

Do mesmo modo, os "prazos e termos previstos em regulamento" para o exercício de requerimentos pelo titular de dados pessoais em face de controladores e operadores, a que alude o $\S 5^{\circ}$ do art. 18 , devem ser entendidos como funcionalizados a uma tutela efetiva do direito à privacidade, afastando-se, assim, a legitimidade de eventual regulamentação setorial que esvazie a utilidade, para o titular, dos mecanismos previstos pela LGDP.

Vale destacar, ainda, a prerrogativa prevista pelo inciso IX do art. 18 no sentido da revogação do consentimento, pelo titular de dados pessoais, para o tratamento dos mesmos. A possibilidade de revogação das manifestações de vontade é considerada ínsita a todo tipo de exercício de autonomia existencial. ${ }^{57} \mathrm{~A}$ faculdade prevista pela lei, portanto, há de ser interpretada como parte do conteúdo do direito extrapatrimonial à privacidade, o que contribuiu para balizar os limites ao seu exercício.

Nesse sentido, o único limite declarado pela LGPD à revogação prevista pelo inciso IX do art. 18 é a norma do art. $8^{\circ}, \S 5^{\circ}$, que determina a irretroatividade da revogação (confirmando, assim, a legitimidade do tratamento realizado desde o consentimento original até o momento em que o titular revoga sua anuência), para além das hipóteses de dispensa de consentimento (por exemplo, aquela prevista pelo art. $7^{\circ}, \S^{\circ}$ ) e dos casos em que se autoriza a conservação dos dados pessoais mesmo após o término do tratamento (art. 16). Como todo exercício de situações jurídicas, porém, inclusive aquelas de natureza existencial, o recurso à revogação se sujeita a um juízo valorativo, sendo possível, ao menos em tese e com a devida cautela, que certos casos de revogação venham a se revelar, em concreto, como exercício disfuncional da prerrogativa do inciso IX, passível de repressão total ou parcial, na medida da abusividade verificada.$^{60} \mathrm{Se}$ a análise criteriosa das circunstâncias fáticas, à luz dos interesses e valores relevantes no caso concreto, indicar o exercício abusivo do direito à revogação do consentimento, a subsequente repressão consistirá, via de regra, na deflagração do dever de indenizar, não parecendo razoável cogitar, no mais das vezes, da ineficácia da revogação. A advertência afigura-se particularmente adequada para os dados pessoais sensíveis, em razão da maior intensidade da tutela que lhes deve ser dispensada (MULHOLLAND, 2018, p. 165 e ss.).

Lamenta-se, neste particular, portanto, que a LGPD, embora tenha acertadamente atentado, em diversos dispositivos, à distinção entre dados sensíveis e dados econômicos (notadamente na Seção II

55 O art. 759 do Código Civil estabelece, nesse sentido, ao tratar da declaração inicial do risco, que a proposta deve conter "[...] a declaração dos elementos essenciais do interesse a ser garantido e do risco". Para o maior desenvolvimento da questão atinente ao conteúdo da declaração inicial do risco, v., por todos, na doutrina contemporânea, Petersen (2018, p. 131 e ss.).

56 No que tange especificamente à identificação do parâmetro de análise dos deveres de informação decorrentes da boa-fé objetiva e à promoção, já se pôde afirmar: "Seja qual for a denominação atribuída à manifestação concreta do dever de informação, o fato é que da cláusula geral de boafé objetiva decorre a necessidade de oportunização, a todos os envolvidos, do conhecimento das informações relevantes ao desenvolvimento e deslinde de uma dada relação obrigacional. A menção à relevância das informações faz-se de sensível destaque, no que tange ao objeto precípuo do presente estudo, uma vez que nem toda omissão ou má prestação de informação será suficiente à caracterização de inadimplemento contratual" (SILVA, 2017a, p. 303-304. Grifos no original)

57 A respeito da autonomia existencial, esclarece Rose Melo Vencelau Meireles (2009, p. 246) que "a revogabilidade decorre do princípio do consentimento qualificado, sobretudo, quando da disposição resulte limitação ao exercício de direito da personalidade, pois somente a limitação voluntária é admissível. Permite-se que o disponente se arrependa da declaração de vontade que expressou e a revogue, até o momento anterior ao da execução material do ato".

60 "Nesse diapasão, o instituto do abuso fornece valioso instrumento para a ainda frágil disciplina jurídica dos atos de autonomia existencial. Embora nem sempre se identifique parte legítima para alegar o abuso nas situações dessa natureza, o controle funcional do exercício mostra-se essencial nos casos em que houver interesse legítimo contraposto. Esse interesse pode integrar a função da situação subjetiva desde sua gênese (é o caso do abuso do poder familiar), ou especificar-se pela violação da regra geral de não lesar ninguém (ilustrativamente, na hipótese da revogação de certas escolhas existenciais que venha a ocasionar dano a terceiros). Em qualquer caso, se outro interesse, além daquele do titular, estiver integrado à função da situação jurídica, não será sua natureza existencial a impedir o controle de abusividade do exercício" (SOUZA, 2015a, p. 2295). 
de seu Capítulo II), não tenha feito qualquer gradação da tutela dispensada a essas duas categorias de dados no Capítulo III, onde dispôs sobre os "direitos" do titular. ${ }^{61}$ De fato, como se sabe, os dados ditos econômicos, isto é, aqueles que não traduzem informações que possam expor o indivíduo a discriminações lesivas à sua dignidade (ao contrário dos dados sensíveis), costumam receber uma tutela menos intensa, situando-se em uma zona periférica do direito à privacidade, ${ }^{62} \mathrm{o}$ que talvez permitisse afastar ou, ao menos, restringir a liberdade de revogação do consentimento quanto ao tratamento dos mesmos.

Como se extrai das considerações acima, a compreensão dos instrumentos previstos, no Capítulo III da LGPD, como remédios legais, e não como direitos autônomos, preenche de conteúdo valorativo esses mecanismos (conteúdo esse herdado do direito à privacidade e de sua inserção do tecido axiológico do sistema), o que evita que tais prerrogativas, eminentemente procedimentais ou instrumentais, passem a ser interpretadas como poderes absolutos. Torna-se possível, assim, não apenas uma compreensão mais minuciosa acerca do funcionamento de tais instrumentos, mas também um controle valorativo eficaz do exercício dessas prerrogativas pelo titular de dados pessoais. Impõe-se, por outro lado, analisar outra dúvida hermenêutica que pode exsurgir da qualificação de tais previsões como remédios - a saber, a da suposta taxatividade das previsões legais de tutela da privacidade do titular de dados pessoais. É o que se passa a expor.

\section{Crítica à suposta taxatividade dos remédios previstos pela LGPD}

No intuito de ilustrar a questão de fundo sobre os contornos do sistema remedial - destacadamente, a sua suposta taxatividade -, parece válido o recurso a um dos exemplos mais emblemáticos da questão, consistente no regime processual da tutela inibitória no direito brasileiro. Como se sabe, a tutela inibitória pode ter por escopo impedir a prática de atos antijurídicos, ou inibir a sua repetição ou continuação. ${ }^{63} \mathrm{Em}$ qualquer dessas manifestações, distingue-se da tutela dita repressiva, a qual se caracteriza pelo escopo de remoção dos efeitos de uma antijuridicidade já perpetrada. ${ }^{64}$ Sua relevância reside precisamente na possibilidade de promoção da tutela das situações jurídicas subjetivas na sua fase fisiológica, e não somente naquela patológica, em razão da aptidão das medidas inibitórias para evitar a consumação ou renovação da lesão a um interesse reputado merecedor de tutela. ${ }^{65}$ Avulta, assim, a importância da tutela inibitória (sobretudo aquela efetivada em caráter preventivo à consumação de qualquer ato antijurídico) para a promoção do próprio ideal de efetividade da tutela dos direitos. ${ }^{66}$

61 Para uma análise do tratamento especial dispensado aos chamados dados sensíveis pela referida Seção II do Capítulo II da LGPD, v. Santos e Taliba (2018, item 4).

62 Sobre essa tutela menos intensa dos dados econômicos e sua relevância para o conteúdo contemporâneo da noção de privacidade, veja-se a lição de Stefano Rodotà (2008, p.78): "Procura-se individuar o 'núcleo duro' da privacidade em torno dos dados relativos a opiniões políticas, sindicais ou de qualquer outro gênero, fé religiosa, raça, saúde, hábitos sexuais. Ao mesmo tempo, tende-se a liberalizar a circulação de informações pessoais de cunho econômico".

63 Afirma-se: "A tutela inibitória possui três modalidades. A primeira [...] visa a impedir a prática do ilícito, podendo atuar antes que qualquer ilícito tenha sido praticado. As outras duas visam a inibir a repetição e a continuação do ilícito, nos casos de ilícito já praticado. Exemplo de ação ilícita continuada é a atividade que gera fumaça poluente e de ação ilícita repetida o despejo de lixo tóxico no ambiente" (PITERMAN, 2017, p. 45).

64 "Enquanto a tutela inibitória visa a impedir a prática, a repetição ou a continuação do ilícito, a tutela de remoção do ilícito ou reintegratória, por sua vez, destina-se a remover os efeitos de uma ação ilícita que já ocorreu, como, por exemplo, aprender produtos nocivos à saúde de consumidores já expostos à venda" (PITERMAN, 2017, p. 45). Cumpre registrar que se está tomando, neste ponto do estudo, a noção de "ilícito" no sentido amplo de ato contrário à ordem jurídica e, portanto, não necessariamente correlacionado ao fenômeno da responsabilidade civil.

65 "A prospectada leitura teleológico-funcional do sistema remedial permite reconhecer na ação inibitória uma técnica a ser ativada especialmente na via preventiva, na fase fisiológica da realização de interesses juridicamente relevantes e não somente naquela patológica da lesão dos interesses. Pressuposto da inibitória, de fato, não é o ilícito - que pode até mesmo faltar -, mas o dano, seja apenas temido e ainda mais se potencialmente irreparável" (PERLINGIERI, 2011, p. 20. Tradução livre).

66 "É necessário admitir que um modelo de tutela civil dos direitos, que queira ser efetivo e não virtual, deveria abandonar o seu tradicional caráter agnóstico voltado para o ilícito e a violação dos direitos, caráter ínsito no fato de que ele intervém apenas para reprimir violações já ocorridas e remover, se possível, as suas consequências. Deveria exercer também uma função preventiva das violações e isso em situações de fato que as deixem ser presumidas" (MAJO, 1989, p. 377. Tradução livre). 
Por tais razões, resultaria contraditória a enunciação de uma suposta taxatividade das medidas inibitórias. ${ }^{67}$ Uma formulação de tal natureza acarretaria o risco de diminuição considerável da efetividade da tutela prometida pelo intérprete-operador do direito ao término do processo de individualização da normativa do caso concreto. A doutrina tem reconhecido, ao revés, que um modelo rígido de taxatividade da tutela inibitória não se compatibiliza com o projeto constitucional de efetividade da tutela a ser dispensada aos direitos. ${ }^{68}$ Com efeito, o campo de abrangência das ações inibitórias há de ser tão amplo quanto a esfera de situações jurídicas subjetivas que venham a ser concretamente reputadas merecedoras de tutela. ${ }^{69}$

$\mathrm{Na}$ contramão de tais observações, a jurisprudência brasileira tende a resolver muitas questões em torno da tutela inibitória, em alguma medida, a partir da assunção da taxatividade dos remédios no direito privado - embora tal atributo seja mais implícito do que explicitamente enunciado. ${ }^{70} \mathrm{Um}$ bom exemplo se extrai de caso paradigmático envolvendo justamente uma questão de merecimento de tutela do exercício do direito à privacidade ${ }^{71}$ (embora não propriamente de tratamento de dados pessoais). Trata-se do julgamento proferido pelo Supremo Tribunal Federal sobre as biografias não autorizadas, em que a Corte reconheceu um "(a)parente conflito entre princípios constitucionais: liberdade de expressão, de informação, artística e cultural, independente de censura ou autorização prévia (art. $5^{\circ}$ incs. IV, IX, XIV; $220, \S \S 1^{\circ}$ e $2^{\circ}$ ) e inviolabilidade da intimidade, vida privada, honra e imagem das pessoas (art. $5^{\circ}$, inc. X)".$^{72}$ Ao reconhecer uma suposta primazia da liberdade de expressão, ${ }^{73}$ a Corte concluiu pela absoluta desnecessidade de autorização prévia do biografado ou de seus familiares. ${ }^{74}$ Destacou-se, assim, que nem mesmo o risco iminente de lesão aos direitos da personalidade justificaria a concessão de ordem judicial proibitiva, relegando-se à via ressarcitória a reparação dos possíveis danos sofridos pela vítima. ${ }^{75}$

67 "O campo de aplicação de tal medida [inibitória] é usualmente limitado às fattispecie para as quais é expressamente prevista ex lege, embora às vezes as relativas disposições normativas sejam consideradas suscetíveis de interpretação analógica. No entanto, essa orientação não convence. Há interesses que, à luz [...] do complexo dos princípios fundamentais do ordenamento, não podem ficar sem proteção devido à ausência de uma norma específica que permita o recurso à inibitória ou dos pressupostos para a aplicação analógica da mesma" (PERLINGIERI, 2011, p. 18-19. Tradução livre). O autor arremata: "Para concluir, a idoneidade de qualquer instrumento de proteção para atender à necessidade específica de tutela impõe a superação do pseudo-princípio da tipicidade, que parece informar o ordenamento em todas as áreas (desde as disposições sobre o tema da publicidade até aquelas sobre os remédios)". Semelhante conclusão é também corroborada, à luz do direito brasileiro, por Silva (2019, item 4).

68 "A preocupação é direcionada para o futuro e não para o passado, o leva à afirmação de que as ordens inibitórias dos juízes, disseminadas no código ou em outras leis, não representam uma espécie 'isolada', mas sim a expressão de um remédio mais geral, de fato inibitório, que encontra o seu fundamento na exigência de prevenir as violações [...]" (MAJO, 1989, p. 378. Tradução livre).

69 "[...] o remédio inibitório é admissível em todas as hipóteses nas quais se consinta a efetiva implementação de um interesse merecedor de tutela: 'a extensão da inibitória é efetuada não por meio de uma interpretação ampliativa ou analógica, mas baseando-se no princípio de adequação do remédio em relação ao interesse substancial”" (PERLINGIERI, 2011, p. 19, nota de rodapé n. 49). O autor arremata: "O remédio, se encontrar justificativa no merecimento de tutela da situação jurídica subjetiva lesada e nos valores que merecem prevalência, deve sempre ter aplicação" (PERLINGIERI, 2011, p. 19-20).

70 Ilustrativamente: "[...] A concessão de tutela inibitória em face de jornalista, para que cesse a postagem de matérias consideradas ofensivas, se mostra impossível, pois a crítica jornalística, pela sua relação de inerência com o interesse público, não pode ser aprioristicamente censurada. 5. Sopesados o risco de lesão ao patrimônio subjetivo individual do autor e a ameaça de censura à imprensa, o fiel da balança deve pender para o lado do direito à informação e à opinião. [...] Mesmo para casos extremos como o dos autos - em que há notícia de seguidos excessos no uso

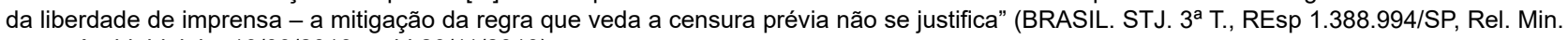
nancy Andrighi, julg. 19/09/2013, publ.29/11/2013).

71 Para uma análise do exemplo das biografias como um problema de merecimento de tutela envolvendo o direito à privacidade, remete-se a Souza (2014, p. 97 e ss.)

72 BRASIL. STF. Tribunal Pleno. ADI 4.815/DF, Rel. Min. Cármen Lúcia, julg. 10/06/2015, publ. 01/02/2016.

73 Trata-se de tendência que parece remontar, ao menos, ao julgamento da ADPF 130, em que o Supremo Tribunal Federal entendeu pela não recepção da Lei de Imprensa (Lei n. 5.250/1967), por considerá-la atentatória àquilo que a Corte reconheceu como "superiores bens de personalidade": "A plenitude da liberdade de imprensa como reforço ou sobre tutela das liberdades de manifestação do pensamento, de informação e de expressão artística, científica, intelectual e comunicacional. Liberdades que dão conteúdo às relações de imprensa e que se põem como superiores bens de personalidade" (BRASIL. STF. Tribunal Pleno. ADPF 130/DF, Rel. Min. Carlos Britto, julg. 30/04/2009, publ. 06/11/2009). Para uma crítica a esta concepção, cf. BODIN DE MORAES; SOUZA, (2017, p. 7 e ss.)

74 Colhe-se da ementa: "A Constituição do Brasil proíbe qualquer censura. O exercício do direito à liberdade de expressão não pode ser cerceada pelo Estado ou por particular” (BRASIL. STF. Tribunal Pleno. ADI 4.815/DF, Rel. Min. Cármen Lúcia, julg. 10/06/2015, publ. 01/02/2016).

75 Colhe-se da ementa: "Autorização prévia para biografia constitui censura prévia particular. O recolhimento de obras é censura judicial, a substituir a administrativa. O risco é próprio do viver. Erros corrigem-se segundo o direito, não se coartando liberdades conquistadas. A reparação de danos e o direito de resposta devem ser exercidos nos termos da lei. A liberdade é constitucionalmente garantida, não se podendo anular por outra norma constitucional (inc. IV do art. 60), menos ainda por norma de hierarquia inferior (lei civil), ainda que sob o argumento de se estar a resguardar e proteger outro direito constitucionalmente assegurado, qual seja, o da inviolabilidade do direito à intimidade, à privacidade, à honra e à imagem" (BRASIL. STF. Tribunal Pleno. ADI 4.815/DF, Rel. Min. Cármen Lúcia, julg. 10/06/2015, publ. 01/02/2016). Cumpre registrar, ainda, o dispositivo do acórdão, conforme resumido na ementa da decisão: "Ação direta julgada procedente para dar interpretação conforme à Constituição aos arts. 20 e 21 do Código Civil, sem redução de texto, para, em consonância com os direitos fundamentais à liberdade de pensamento e de sua expressão, de criação artística, produção científica, declarar inexigível autorização de pessoa biografada relativamente a obras biográficas literárias ou audiovisuais, sendo também desnecessária autorização de pessoas retratadas como coadjuvantes (ou de seus familiares, em caso de pessoas falecidas ou ausentes)" (BRASIL. STF. Tribunal Pleno. ADI 4.815/DF, Rel. Min. Cármen Lúcia, julg. 10/06/2015, publ. 01/02/2016). 
Em termos metodológicos, como se percebe, a discussão sobre o cabimento ou não da tutela inibitória não se pode perfazer sem uma investigação da correlata questão de fundo atinente à operatividade dos mecanismos inibitórios no sistema remedial brasileiro, bem como uma investigação da concreta adequação dos remédios (entre eles, os inibitórios) à efetiva tutela dos interesses reputados merecedores de tutela à luz das circunstâncias de cada caso. Tais conclusões não se restringem aos remédios de índole inibitória, sendo imperativo revisitar a suposta taxatividade de todas as espécies remediais no direito privado. ${ }^{76}$ Avulta, nesse paradigma, a insuficiência dos modelos legais predefinidos em matéria de remédios (PERLINGIERI, 2011, p. 7). ${ }^{77}$ Sequer parece possível, em realidade, conceber uma categoria remedial em termos rígidos, uma vez que somente em perspectiva funcional se pode reconhecer o interesse merecedor de tutela e, assim, se perquirir o instrumento mais efetivo para a implementação dessa tutela no caso concreto. ${ }^{78}$ Eis os contornos gerais de uma renovada concepção metodológica sobre a flexibilidade do sistema remedial (SILVA, 2019, item 4). ${ }^{79}$

A variabilidade e a flexibilidade ora atribuídas aos remédios encontram fundamento positivo mais imediato na garantia constitucional de efetividade da tutela jurisdicional dos direitos (PERLINGIERI, 2010b, p. 196-197; MAZZAMUTO; PLAIA, 2012, p. 16). Tal garantia corresponde ao substrato material extraído da previsão, contida no artigo $5^{\circ}$, inciso XXXV, da CF, acerca da inafastabilidade do controle jurisdicional. ${ }^{80}$ Cumpre notar, ainda, que uma série de dispositivos do CPC/2015 busca promover o ideal de efetividade da tutela jurisdicional, valendo destacar, exemplificativamente, a previsão do artigo $6^{\circ}$ do diploma processual, segundo a qual "(t)odos os sujeitos do processo devem cooperar entre si para que se obtenha, em tempo razoável, decisão de mérito justa e efetiva". Semelhante ordem de preocupação se reflete na disciplina de diversas questões, tais como os poderes do juiz (artigo 139, inciso $\mathrm{VI}$ ), os instrumentos gerais para a tutela provisória (artigo 297), os instrumentos para a tutela provisória de urgência (artigo 301), a exibição de documentos (artigo 403), o cumprimento de sentença (artigo 536), entre outras.

O imperativo de efetividade parece ser a razão subjacente à própria disciplina dispensada pelo CPC ao julgamento das ações relativas às prestações de fazer, de não fazer e de entregar coisa. Verifica-se, com efeito, uma expressiva preocupação do diploma processual com a garantia da tutela das situações jurídicas creditícias sem a previsão de um rol supostamente taxativo. Em realidade, o estatuto processual contém previsões emblemáticas no sentido de resguardar a situação jurídica creditícia não só pela tutela específica (no sentido de cumprimento coercitivo da própria obrigação inadimplida), mas igualmente pela

76 Precisamente nesse sentido, Pietro Perlingieri afirma que se afigura útil “[...] refletir sobre a conveniência de conceber o remédio como uma reação taxativamente ligada à violação de um interesse típico [...]. O remédio é uma ferramenta que se adapta ao interesse que se pretende tutelar e que é reconhecido pelo ordenamento" (PERLINGIERI, 2010c, p. 315. Tradução livre).

77 A ilustrar a relevância da presente reflexão em matéria de proteção de dados, pode-se mencionar o questionamento sobre a consagração ou não de um direito à explicação pela LGPD. Ao propósito, v. Monteiro (2018, passim.)

78 'Uma 'categoria' dos remédios, derivada do direito positivo, se fosse possível construí-la, se revelaria totalmente inútil. A questão deve ser abordada, antes de tudo, em chave funcional, rejeitando esquemas rígidos. Como antecipado, não é o interesse a estruturar-se em torno do remédio, mas o remédio a encontrar modulação em função dos interesses considerados pela fattispecie concreta. Deve-se, em suma, discutir a flexibilidade do sistema remedial" (PERLINGIERI, 2011, p. 4-5. Tradução livre). O autor arremata: "Em definitivo, as tentativas de reconstrução do complexo remedial operadas pela doutrina resultam, na maior parte, contraditórias e incertas” (PERLINGIERI, 2011, p. 7. Tradução livre).

79 Exemplo de aplicação das referidas premissas se encontra na disciplina dos remédios ao inadimplemento contratual, em Silva (2018, passim.).

80 Assim conclui a doutrina processualista nacional: "A sua vez, a efetividade está consagrada no art. $5^{\circ}, X X X V$, da CF/1988, pois não é suficiente tão somente abrir a porta de entrada do Poder Judiciário, mas prestar jurisdição tanto quanto possível eficiente, efetiva e justa [...]. Advirta-se, além disso, que a efetividade vigora seja em relação ao direito já lesionado seja quanto aquele simplesmente ameaçado (art. $5^{\circ}$, XXXV, da CF/1988), abrangendo assim a tutela preventiva substancial e definitiva, além da meramente provisória ou temporária" (OLIVEIRA, 2006, item 3). No mesmo sentido, v., na doutrina civilista, Bodin de Moraes (2017, p. 7). Ao identificar fundamento constitucional da garantia de efetividade dos remédios no âmbito do direito italiano, Adolfo di Majo (1989) faz referência à "[...] prescrição constitucional segundo a qual 'todos podem agir em juízo para a proteção dos próprios direitos e interesses legítimos' (artigo 24 da Constituição), prescrição que, segundo alguns (Andrioli), é um sinal claro de uma garantia de efetividade, mas não já no sentido de uma abstrata 'justiciabilidade' do direito e/ou interesse, mas da existência de um remédio concreto que garanta a sua satisfação ou que, de qualquer forma, desencoraje a sua insatisfação" (1989, p. 372. Tradução livre). O autor prossegue: "A este respeito, é útil mencionar a opinião (Taruffo) de quem entende que a exigência, constitucionalmente garantida, de efetividade da tutela não pode se considerar satisfeita com a previsão de um qualquer remédio judicial, mas um remédio em função do conteúdo que é próprio do direito" (MAJO, 1989, p. 372. Tradução livre). 
tutela pelo resultado prático equivalente (no sentido ${ }^{81}$ de promoção da finalidade útil do contrato sem o cumprimento da obrigação nos termos pactuados).

Nesse cenário, nota-se que o atendimento aos comandos legais e constitucionais dependerá, necessariamente, não apenas da possibilidade de acesso ao Poder Judiciário ou mesmo da previsão abstrata de instrumentos de tutela, mas sim da disponibilização dos remédios mais idôneos à tutela efetiva dos interesses reputados merecedores de tutela em cada caso concreto. ${ }^{82}$ Impende, assim, evitar ao máximo o risco de que a variabilidade e a flexibilidade do sistema remedial sejam afetadas por uma interpretação formalista das regras sobre o processo civil, bem como dos remédios não processuais legislativamente previstos (PERLINGIERI, 2011, p. 10). Compreende-se, enfim, a necessidade de se analisar o inteiro sistema remedial em perspectiva axiológico-funcional, que permita conceber a noção de remédio como todo instrumento idôneo a efetivar um interesse, na constante busca pela efetividade e adequação da tutela das situações juridicamente relevantes. ${ }^{83}$

Parece ser o caso de se reconhecer, como anunciado, a impossibilidade de cisão entre a definição do interesse merecedor de tutela e a individualização do remédio respectivo. Com efeito, o raciocínio do intérprete não pode se perfazer apenas com a identificação dos interesses merecedores de tutela, afigurando-se essencial a investigação sobre os mecanismos de concretização dessa chancela jurídica. O estudo dos remédios serve precisamente a investigar os mecanismos mais adequados de proteção e promoção dos interesses no caso concreto. Salta aos olhos, nesse contexto, a relação indissociável entre normas instrumentais, ou procedimentais, e normas materiais (ou seja, aquelas que atribuem efetivas situações jurídicas às partes): as primeiras servem justamente a concretizar a proteção dos interesses reputados merecedores de tutela pelas segundas, razão pela qual não se afigura aconselhável um estudo das medidas legalmente previstas (como aquelas do Capítulo III da LGPD), de modo totalmente dissociado ao direito material.

Advirta-se, por oportuno, que o raciocínio pautado no projeto constitucional de efetividade da tutela dos direitos não autoriza o intérprete a desconsiderar, ipso facto, a disciplina estabelecida na legislação processual pelo legislador ordinário. Em realidade, tal como se verifica a propósito das normas substanciais, também a legitimidade das normas procedimentais e instrumentais decorre da constante investigação da sua compatibilidade, em cada caso concreto, com a tábua axiológica constitucional. Os dispositivos legais refletem, assim, relevantes escolhas legislativas, escolhas essas presumivelmente conformes à Constituição e fruto de uma ponderação prévia abstrata pelo legislador. O que não se pode perder de vista, como ora sustentado, é que tanto normas de conteúdo substancial quanto normas eminentemente procedimentais remontam à tábua axiológica constitucional e devem convergir para a efetividade da tutela aos interesses concretamente considerados merecedores de proteção pelo ordenamento (SILVA, 2019, item 5).

81 Precisamente nesse sentido, o artigo 497 estabelece que, "(n)a ação que tenha por objeto a prestação de fazer ou de não fazer, o juiz, se procedente o pedido, concederá a tutela específica ou determinará providências que assegurem a obtenção de tutela pelo resultado prático equivalente". No que diz respeito à obrigação de entrega de coisa, o artigo 498 igualmente faz referência à concessão judicial da tutela específica. Ainda mais emblemática é a previsão geral do artigo 499, no sentido da denominada prioridade da execução específica e da tutela pelo "resultado prático equivalente" em detrimento da medida (supostamente subsidiária) de resolução do contrato (com os seus efeitos ordinariamente esperados). Para uma crítica às imprecisões técnicas do art. 499 do diploma processual à luz da dogmática civilista, sem embargo da louvável preocupação de enunciação do cabimento amplo (e não taxativo) das medidas de tutela específica, permita-se remeter a Silva (2019, item 4).

82 "O que deve ser reiterado é que a adequação da tutela não pode ser avaliada em abstrato, no que diz respeito à postulação de um juízo, qual que então seja o seu resultado prático, mas à congruência do concreto remédio subministrado (ao êxito do juízo) com o interesse de cuja tutela se trata" (MAJO, 1989, p. 372-373. Tradução livre). Pertinente, ainda, a conclusão alcançada na doutrina processualista: "[...] numa perspectiva dinâmica, a efetividade qualificada implica o direito da parte de obter uma decisão de mérito, adaptada às situações materialmente tuteláveis, levando em conta a crise sofrida pelo direito material e sua adequação às formas diferenciadas de tutela e a segurança, que não pode mais ser vista sob a ótica do Estado Liberal, quando prevalecia como valor; significa o direito da parte ao processo justo, pois, mesmo atendido o formalismo do sistema, o processo pode ser injusto ou conduzir a um resultado injusto" (PITERMAN, 2017, p. 52). O autor prossegue: "[...] para coordenar e equacionar ambos os planos, visando à concretização de um processo justo, existe, no plano material, o direito à tutela dos direitos e, no plano processual, o direito à tutela jurisdicional. Esta deverá ser sempre uma resposta adequada e efetiva àquela, para que se viabilize a tutela de toda a sorte de direitos (individuais e coletivos)" (PITERMAN, 2017, p. 42).

83 "A rejeição das tentativas de conceituação e uma perspectiva axiológico-funcional podem induzir a definir remédio como todo instrumento idôneo para implementar um interesse. Isso não apenas justifica a sua previsão, mas também oferece a sua medida: a proteção das situações juridicamente relevantes deve sempre ser adequada e efetiva" (PERLINGIERI, 2011, p. 8. Tradução livre). V., ainda, Messinetti (2012, p. 104-105). 
Desconsideradas tais premissas, vislumbrar-se-ia um pernicioso cenário, puramente formalista, em que a técnica regulamentar adotada pelo legislador da LGPD, em vez de contribuir para concretizar a tutela que se pretendeu conferir à privacidade, passaria a figurar como verdadeira camisa de força para essa tutela. Nesse sentido, o "direito" de petição do titular de dados pessoais, contra o controlador, perante a recém-criada autoridade nacional ou perante organismos de defesa do consumidor (art. $18, \S \S 1^{\circ}$ e $8^{\circ}$ ), não pode ser lido como a exclusão legal da possibilidade de peticionamento direto ao próprio operador ou controlador (previsto pelo próprio caput do art. 18) ou de qualquer outro agente responsável pelo tratamento de dados que, não tendo sido abrangido pela lei, mostre-se relevante para a tutela dos dados pessoais do interessado ${ }^{84} \mathrm{~A}$ possibilidade de o titular de dados pessoais opor-se ao tratamento realizado com dispensa de consentimento, caso ele ocorra em descumprimento da lei (art. $\left.18, \S 2^{\circ}\right)$, não afasta a mesma possibilidade em casos de lesão ao direito à privacidade do titular que não tenham sido expressamente tipificados pelo diploma, muito menos exclui a possibilidade de oposição nos casos em que houve consentimento do titular.

A previsão de que os "direitos" previstos no art. 18 devem ser exercidos mediante requerimento expresso do titular (art. 18, $\S 3^{\circ}$ ) não afasta o dever dos agentes que realizam tratamento de dados de adotarem todas as práticas necessárias para respeitarem tais garantias, independentemente de provocação, nem impede que o titular interessado formule reclamações não contempladas no dispositivo normativo, nem afasta a legitimidade do Ministério Público ou de entidades voltadas à tutela de interesses supraindividuais em peticionarem em favor de grupos determinados, ou não, de titulares de dados. Nesse sentido, quando o art. 22 reconhece que "a defesa dos interesses e dos direitos dos titulares de dados poderá ser exercida em juízo, individual ou coletivamente, na forma do disposto na legislação pertinente, acerca dos instrumentos de tutela individual e coletiva", não se há de entender que eventual contencioso administrativo, por não estar mencionado na norma, fique restrito à esfera individual. Ao contrário, como já ressaltado em doutrina, embora se celebre a ampliação de instrumentos individuais de tutela (sobretudo o livre acesso), a atuação de tais entes pode ajudar de forma significativa a suprir os déficits que reduzem a efetividade da tutela individual buscada pelo próprio titular (notadamente, o déficit informacional). ${ }^{85}$

Na mesma direção, a prerrogativa de portabilidade dos dados pessoais, a pedido do titular, para "outro fornecedor de serviço ou produto", "observados os segredos comercial e industrial, de acordo com a regulamentação do órgão controlador", de que trata o art. $18, \mathrm{~V}$ e $\S 7^{\circ}$, não impede eventuais pedidos de portabilidade para agentes que não se enquadrem na qualificação de "fornecedor", que é ínsita às relações de consumo (art. $3^{\circ}$ do CDC). Ao contrário, trata-se apenas de mais uma manifestação do conteúdo da autodeterminação informativa, que permite ao titular controlar o destino conferido às informações que circulam sobre ele próprio. Do mesmo modo, a negativa de atendimento ao requerimento do titular pelo controlador, admitida pelo $\S 4^{\circ}$ do art. 18 , sob alegação de não ser o agente responsável pelo tratamento dos dados em questão, ou de haver razões de fato ou de direito que impeçam a adoção imediata da medida requerida, não pode ser interpretada como um salvo-conduto autorizador de negativas arbitrárias pelos agentes, aos quais se impõe delicado ônus probatório, sobretudo diante do déficit informacional verificado em relação ao titular dos dados pessoais, que quase sempre carecerá de meios para avaliar se a negativa foi ou não infundada (e, consequentemente, ilícita) ${ }^{86}$

84 "É interessante notar que, nos termos do art. 18, os direitos dos titulares são direcionados ao controlador, o que pode ser considerado uma falha técnica, pois, como se verá adiante, ao se tratar dos deveres e responsabilidades dos agentes de tratamento, vários deles também serão oponíveis aos operadores e encarregados. Melhor teria sido se o legislador brasileiro, a exemplo do Regulamento Europeu, tivesse identificado como titular dos deveres os responsáveis pelo tratamento de dados, categoria mais ampla que abrange, mas não se restringe, ao controlador, nos termos das definições constantes do próprio art. $5^{\circ}$, da LGPD" (FRAZÃO, 2018b).

85 Veja-se, a esse propósito, a lição de Stefano Rodotà (2008, p. 68), que destaca a relevância de que, para tornar mais eficaz o acesso, os indivíduos contem com um acesso "assistido" por especialistas, e remata: "Ainda mais importante revela-se o reconhecimento de um direito de acesso individual 'integrado' pela presença de um sujeito coletivo (sindicato, associação de direitos civis, associação de tutela de consumidores e assim por diante). Seria necessária, aliás, a previsão de uma legitimação autônoma de acesso de tais sujeitos coletivos, mesmo se temperada pelo consentimento do interessado: tais sujeitos, de fato, poderiam assumir, entre as suas funções institucionais, a do exercício sistemático do direito de acesso, realizando assim um efetivo controle sobre os coletores das informações".

86 Aluda-se, ainda uma vez, à lição de Stefano Rodotà (2008, p. 57), que, ao ponderar sobre a construção ideal de um sistema normativo de proteção de dados pessoais, adverte: "Uma análise correta do problema requer uma reflexão realista sobre os sujeitos e os interesses em questão, especialmente para verificar se os sujeitos implicados nas transações relacionadas às informações não revelam excessiva disparidade de poder, visto que a intervenção legislativa teria justamente a função de reconstruir as condições de base para o funcionamento adequado das próprias regras de mercado". 
A previsão do conteúdo da declaração de existência de tratamento ou acesso a dados pessoais pelo art. 19, II ("por meio de declaração clara e completa, que indique a origem dos dados, a inexistência de registro, os critérios utilizados e a finalidade do tratamento, observados os segredos comercial e industrial"), não deve excluir a exigibilidade de outras informações pelo titular que se mostrem merecedoras de tutela no caso concreto - sendo sempre necessária, portanto, uma ponderação entre os interesses do titular e os do agente, inclusive quanto ao ônus (relevante ou não) criado para este pelo pedido de informações. ${ }^{87}$ A ressalva quanto aos segredos comercial e industrial, feita também pelos arts. $19, \S 3^{\circ}$, e $20, \S 1^{\circ}$, no que diz respeito aos pedidos de informações, e pelo art. 18, V, no que diz respeito aos pedidos de portabilidade, deve ser interpretada cuidadosamente, evitando a invocação disfuncional dessas escusas pelo agente, que deve demonstrar de que modo o pedido formulado pelo titular prejudicaria sua atividade econômica.

Mostra-se muito bem-vinda, nesse sentido, a previsão do art. $20, \S 2^{\circ}$, segundo a qual, em caso de negativa fundada no sigilo comercial ou industrial, "a autoridade nacional poderá realizar auditoria para verificação de aspectos discriminatórios em tratamento automatizado de dados pessoais". A previsão, que visa a coibir negativas abusivas, deve ser estendida analogicamente a todos os casos de negativa fundada em tais alegações, e não apenas aqueles contemplados pelo art. 20 ("decisões tomadas unicamente com base em tratamento automatizado de dados pessoais").

Mais ainda, vale destacar que o fato de o art. 19, em seu $\S 3^{\circ}$, prever que, "quando o tratamento tiver origem no consentimento do titular ou em contrato, o titular poderá solicitar cópia eletrônica integral de seus dados pessoais" não pode excluir, por evidente, o livre acesso a dados cujo tratamento não tenha sido originado pela vontade do titular, inclusive com o fornecimento de cópia integral dos mesmos, sempre que o agente responsável pelo tratamento não apresentar qualquer motivo legítimo para eventual negativa. Analogamente, a previsão do art. 20 , no sentido de que "o titular dos dados tem direito a solicitar a revisão de decisões tomadas unicamente com base em tratamento automatizado de dados pessoais que afetem seus interesses", evidentemente não exclui o direito amplo de revisão de decisões tomadas com base em seus dados pessoais se caracterizado uso discriminatório desses dados, desvio de finalidade do tratamento dos mesmos, dentre outras irregularidades.

\section{Considerações finais}

As considerações anteriores, de cunho meramente ilustrativo (dentre as muitas interpretações equivocadas que poderiam vir a ser conferidas ao rol de remédios previsto pela LGPD), buscam tão somente evidenciar o risco de uma perspectiva formalista, que atribuísse ao sistema remedial da lei um indevido caráter taxativo. Tendo o legislador brasileiro optado por uma técnica regulamentar minuciosa para tratar da matéria (e não uma via predominantemente principiológica, a partir da enunciação de cláusulas gerais), impõe-se a particular cautela do intérprete, que não deve olvidar da ampla diversidade dos remédios adequados à proteção dos interesses do titular de dados que se mostrem legítimos no caso concreto. Impõese, ainda, particular cuidado na compatibilização dos remédios previstos pela LGPD com as disposições, ainda vigentes, dos diplomas que a antecederam, como o CDC, a Lei de Acesso à Informação e o Marco Civil da Internet, na medida em que a nova lei não avocou para si o papel de organizar o inteiro sistema remedial brasileiro na matéria, preservando, ao menos parcialmente, sua fragmentação. Invoca-se, aqui, a reflexão de Stefano Rodotà (2008, p. 89), que indagava:

Será que se poderia afirmar, neste momento, que uma determinada maneira de encarar a proteção dos dados estaria irremediavelmente superada e que o único caminho a seguir seria, de fato, o das disciplinas pontuais, setoriais, estruturadas com base em proibições e procedimentos rígidos, renunciando a uma perspectiva (ou ilusão) de controle?

87 Para uma análise do art. 19, II, da LGPD, v. Frazão (2018b). 
Respondia o autor:

O abandono da disciplina das cláusulas gerais efetivamente aumentaria a rigidez do sistema e, logo, o tornaria ainda menos apropriado para acompanhar a rapidez das mudanças tecnológicas. $E$ o consequente enfraquecimento do momento do controle tornaria ainda mais precária a perspectiva de uma distribuição de poderes mais equilibrada (RODOTÀ, 2008, p. 89).

Renova-se, uma vez mais e sempre, a importância central da doutrina para o enfrentamento das questões atuais e daquelas que se tornarão antigas tão logo deixem de ser futuras.

\section{Referências}

ALMEIDA, Carlos Ferreira de; CARVALHO, Jorge Morais. Introdução ao direito comparado. 3. ed. Coimbra: Almedina, 2017.

AMARAL, Francisco. Direito civil: introdução. 7. ed. Rio de Janeiro: Renovar, 2008.

BARKER, Kit. Rescuing remedialism in unjust enrichment law: why remedies are right. Cambridge Law Journal, Cambridge, v. 57, n. 2, p. 301-327, 1998, item IV.

BIRKS, Peter. Adjudication and interpretation in the common law: a century of change. Legal Studies, Berkeley, v. 14, n. 2, jul. 1994.

BIRKS, Peter. Three kinds of objection to discretionary remedialism. Western Australian Law Review 1, Perth, v. 29, p.1-17, mar. 2000.

BODIN DE MORAES, Maria Celina. A caminho de um direito civil-constitucional. In: BODIN DE MORAES, Maria Celina. Na medida da pessoa humana: estudos de direito civil-constitucional. Rio de Janeiro: Renovar, 2010a. p. 3-20.

BODIN DE MORAES, Maria Celina. Ampliando os direitos da personalidade. In: BODIN DE MORAES, Maria Celina. Na medida da pessoa humana: estudos de direito civil-constitucional. Rio de Janeiro: Renovar, 2010b. p. 121-148.

BODIN DE MORAES, Maria Celina. Do juiz boca-da-lei à lei segundo a boca-do-juiz: notas sobre a aplicação-interpretação do direito no início do Século XXI. Revista de Direito Privado, São Paulo, ano 14, v. 56, p.11-30, out./dez. 2013.

BODIN DE MORAES, Maria Celina. Prescrição, efetividade dos direitos e danos à pessoa humana. Civilistica.com, Rio de Janeiro, ano 6, n.1, p. 7, 2017.

BODIN DE MORAES, Maria Celina; SOUZA, Eduardo Nunes de. Educação e cultura no Brasil: a questão do ensino domiciliar. Civilistica.com, Rio de Janeiro, ano 6, n. 2, p.1-33, 2017.

BUSNELLI, Francesco Donato. La lesione del credito da parte di terzi. Milano: Giuffrè, 1964.

CALABRESI, Guido; MELAMED, A. Douglas. Property rules, liability rules and inalienability: one view of the Cathedral. Harvard Law Review, Cambridge, v. 85, n. 6, p.1089-1128, 1972.

CASTRONOVO, Carlo. L'avventura delle clausole generali. Rivista Critica del Diritto Privato, Bologna, ano IV, mar. 1986.

CUNHA, Antônio Geraldo da. Dicionário etimológico da língua portuguesa. 4. ed. Rio de Janeiro: Lexikon, 2010.

DONEDA, Danilo. Da privacidade à proteção de dados pessoais. Rio de Janeiro: Renovar, 2006.

DONEDA, Danilo; MENDES, Laura. Comentário à nova Lei de Proteção de Dados (Lei 13.709/2018): o novo paradigma da proteção de dados no Brasil. Revista de Direito do Consumidor, São Paulo, v. 120, p. 555-570, nov. /dez. 2018a.

DONEDA, Danilo; MENDES, Laura. R Reflexões iniciais sobre a nova Lei Geral de Proteção de Dados.

Revista de Direito do Consumidor, São Paulo, v. 120, p. 469-483, nov. /dez. 2018b. 
FERREIRA, Aurélio Buarque de Holanda. Novo dicionário Aurélio da língua portuguesa. 4. ed. Atual. Curitiba: Positivo, 2009.

FRAZÃO, Ana de Oliveira. Nova LGPD: demais direitos previstos no art. 18. Jota, São Paulo, 28 nov. 2018a.

FRAZÃO, Ana de Oliveira. Nova LGPD: os direitos dos titulares de dados pessoais. Parte IX. Jota, São Paulo, 17 out. 2018b.

FRIEDMAN, Barry. When rights encounter reality: enforcing federal remedies. Southern California Law Review, Los Angeles, v. 65, p.735-752, 1992.

FRIEDMANN, Daniel. Rights and remedies. In: COHEN, Nili; MCKENDRICK, Ewan (org.). Comparative remedies for breach of contract. Pittsburgh: Hart, 2005. p. 3-17.

GOMES, Orlando. Introdução ao direito civil. 21. ed. atual. Edvaldo Brito e Reginalda Paranhos de Brito. Rio de Janeiro: Forense, 2016.

HARRIS, Donald; CAMPBELL, David; HALSON, Roger. Remedies in contract \& tort. 2. ed. Cambridge: Cambridge University Press, 2005.

KONDER, Carlos Nelson. The range of the right to personal identity in Brazilian civil law. Pensar, Fortaleza, v. 23, n. 1, p.1-11, jan./mar. 2018.

LAYCOCK, Douglas. How remedies became a field: a history. The review of litigation, Austin, v. 27, n. 2, 2008.

LEWICKI, Bruno. Realidade refletida: privacidade e imagem na sociedade controlada. In: TEPEDINO, Gustavo; FACHIN, Luiz Edson (coord.). O direito e o tempo: estudos em homenagem ao Professor Ricardo Pereira Lira. Rio de Janeiro: Renovar, 2008. p. 103-113.

LUPOI, Maurizio. II dolo del debitore: 'dolus' e 'fraud': dal diritto romano all'equity inglese. In: VISINTINI, Giovanna (coord.). Trattato della responsabilità contrattuale: inadempimento e rimedi. Padova: CEDAM, 2009. v. I. p.167-177.

MAGALHÃES, Rodrigo Almeida; DIVINO, Sthéfano Bruno Santos. A proteção de dados e o direito de personalidade da pessoa jurídica. Revista de Direito Empresarial, São Paulo, ano 15, n. 3, p.31-47, set./dez. 2018.

MAJO, Adolfo di. Clausole generali e diritto delle obbligazioni. Rivista Critica del Diritto Privato, [S.I.], ano II, n. 3, p. 539-571, set. 1984.

MAJO, Adolfo di. La tutela dei diritti tra diritto sostanziale e processuale. Rivista Critica del Diritto Privato, [S.I], ano VII, n. 3, p. 363-392, set. 1989.

MAJO, Adolfo di. Le tutele contrattuali. Torino: G. Giappichelli, 2009.

MAZZAMUTO, Salvatore; PLAIA, Armando. I rimedi nel diritto privato europeo. Torino: G. Giappichelli, 2012.

MEIRELES, Rose Melo Vencelau. Autonomia privada e dignidade humana. Rio de Janeiro: Renovar, 2009.

MESSINETTI, Davide. La sistematica rimediale. In: MAZZAMUTO, Salvatore (coord.). Le tutele contrattuali e il diritto europeo: scritti per Adolfo di Majo. Napoli: Jovene, 2012. p. 103-120.

MONTEIRO, Renato Leite. Existe um direito à explicação na lei geral de proteção de dados do Brasil? Artigo estratégico, [S.I.], n. 39, p.1-14, dez. 2018.

MULHOLLAND, Caitlin Sampaio. Dados pessoais sensíveis e a tutela de direitos fundamentais: uma análise à luz da lei geral de proteção de dados pessoais (Lei 13.709/18). Revista de Direito e Garantias Fundamentais, Vitória, v. 19, p.159-180, set./dez. 2018.

NIVARRA, Luca. I nuovi orizzonti della responsabilità contrattuale. Torino: G. Giappiccheli, 2015a. NIVARRA, Luca. Rimedi: un nuovo ordine del discorso civilistico? Europa e Diritto Privato, [S.I.], n. 3, p. 583-611, 2015b. 
OLIVEIRA, Carlos Alberto Álvaro de. O formalismo-valorativo no confronto com o formalismo excessivo. Revista de Processo, [S.I.], v. 137, p. 7-31, jul. 2006.

PEREIRA, Caio Mário da Silva. Instituições de direito civil. 24. ed. atual. Maria Celina Bodin de Moraes. Rio de Janeiro: Forense, 2011. v. I.

PERLINGIERI, Giovanni. Profili applicativi della ragionevolezza nel diritto civile. Napoli: Edizioni Scientifiche Italiane, 2015.

PERLINGIERI, Pietro. Fonti del diritto e "ordinamento del caso concreto". Rivista di Diritto Privato, [S.], ano XV, n. 4, p. 7-28, out./dez. 2010a.

PERLINGIERI, Pietro. II "giusto rimedio" nel diritto civile. II Giusto Processo Civile, [S.I], n. 1, p.1-23, 2011.

PERLINGIERI, Pietro. II principio di legalità nel diritto civile. Rassegna di Diritto Civile, [S.I], ano 31, n. 1, p.164-201, 2010b.

PERLINGIERI, Pietro. La persona e i suoi diritti: problemi del diritto civile. Napoli: Edizioni Scientifiche Italiane, 2005.

PERLINGIERI, Pietro. O direito civil na legalidade constitucional. Trad. Maria Cristina De Cicco. Rio de Janeiro: Renovar, 2008.

PERLINGIERI, Pietro. Regole del mercato e tutela dell'investitore: riflessioni a margine della MiFID. In: ADAMO, S.; CAPOBIANCO, Ernesto; CUCURACHI, P. (a cura di). Regolamentazione del mercato finanziario e contratti con gli investitori. Napoli: Edizioni Scientifiche Italiane, 2010c. p. 307-318.

PETERSEN, Luiza Moreira. O risco no contrato de seguro. São Paulo: Roncarati, 2018.

PINHEIRO, Patrícia Peck Garrido. Nova Lei Brasileira de Proteção de Dados Pessoais (LGPD) e o impacto nas instituições públicas e privadas. Revista dos Tribunais, São Paulo, v. 1000, p. 309-323, fev. 2019.

PITERMAN, Marcel. Direito e processo: tutela dos direitos e tutela jurisdicional na perspectiva dos direitos fundamentais. Revista Jurídica, [S.I.], v. 65, n. 472, p. 27-58, fev. 2017.

RODOTÀ, Stefano. A vida na sociedade da vigilância: a privacidade hoje. Rio de Janeiro: Renovar, 2008.

RODOTÀ, Stefano. II tempo delle clausole generali. Rivista Critica del Diritto Privato, Bologna, v. 5, n. 4, p. 709-733, 1987.

SACCO, Rodolfo. Introdução ao direito comparado. Trad. Vera Jacob de Fradera. São Paulo: Revista dos Tribunais, 2001.

SANTOS, Fabíola; TALIBA, Rita. Lei geral de proteção de dados no Brasil e os possíveis impactos.

Revista dos Tribunais, São Paulo, v. 998, dez. 2018.

SCHREIBER, Anderson. Direitos da personalidade. 3. ed. São Paulo: Atlas, 2014.

SCHREIBER, Anderson. Marco Civil da Internet: avanço ou retrocesso? A responsabilidade civil por dano derivado do conteúdo gerado por terceiro. In: LUCCA, Newton de; SIMÃO FILHO, Adalberto; LIMA, Cíntia Rosa Pereira de Lima (org.). Direito e internet III: Marco Civil da Internet (Lei 12.965/2014). São Paulo: Quartier Latin, 2015. t. II. p. 277-305.

SILVA, Rodrigo da Guia. A revisão do contrato como remédio possível para o inadimplemento. Revista dos Tribunais, São Paulo, v. 995, p.129-155, set. 2018.

SILVA, Rodrigo da Guia. Em busca do conceito contemporâneo de (in)adimplemento contratual: análise funcional à luz da boa-fé objetiva. Revista da AGU, Brasília, v. 16, n. 2, p. 293-322, abr./jun. $2017 a$.

SILVA, Rodrigo da Guia. Remédios no direito privado: tutela das situações jurídicas subjetivas em perspectiva civil-constitucional. Revista de Direito Privado, São Paulo, ano 20, v. 98, p. 255-303, mar./ abr. 2019. 
SILVA, Rodrigo da Guia. Um olhar civil-constitucional sobre a "inconstitucionalidade no caso concreto". Revista de Direito Privado, São Paulo: Revista dos Tribunais, ano 18, v. 73, p.31-62, jan. 2017b.

SMORTO, Guido. II linguaggio dei diritti e il linguaggio dei rimedi. In: GRAZIADEI, Michele; POZZO, Barbara (coord.). Categorie e terminologie del diritto nella prospettiva della comparazione. Milano: Giuffrè, 2015. p. 185-215.

SMORTO, Guido. Sul significato di “rimedi”. Europa e Diritto Privato, Milano, n. 1, 2014.

SOUZA, Allan Rocha de; DONEDA, Danilo; NASCIMENTO, Francisco José Tavares do; GUANAES, Paulo. In: GUANAES, Paulo (org.). Marcos legais nacionais em face da abertura de dados para pesquisa em saúde: dados pessoais, sensíveis, ou sigilosos e propriedade intelectual. Rio de Janeiro: Fiocruz, 2018. p.1-122.

SOUZA, Eduardo Nunes de. Abuso do direito em relações existenciais. Revista Eletrônica Direito e Política, Itajaí, v. 10, n. 4, p. 2278-2301, set./dez. 2015a.

SOUZA, Eduardo Nunes de. Dano à honra pela opinião do entrevistado ou do leitor. In: SCHREIBER, Anderson (org.). Direito e mídia. São Paulo: Atlas, 2015b. p. 304-327.

SOUZA, Eduardo Nunes de. Do erro à culpa na responsabilidade civil do médico: estudo na perspectiva civil-constitucional. Rio de Janeiro: Renovar, 2015c.

SOUZA, Eduardo Nunes de. Situações jurídicas subjetivas: aspectos controversos. Civilistica.com, Rio de Janeiro, ano 4, n. 1, p.1-26, 2015d.

SOUZA, Eduardo Nunes de. Merecimento de tutela: a nova fronteira da legalidade no direito civil. Revista de Direito Privado, São Paulo, ano 15, v. 58, p.75-107, abr./jun. 2014.

SOUZA, Eduardo Nunes de. Nexo causal e culpa na responsabilidade civil: subsídios para uma necessária distinção conceitual. Civilistica.com, Rio de Janeiro, ano 7, n. 3, p.1-58, 2018.

SOUZA, Eduardo Nunes de. Teoria geral das invalidades do negócio jurídico: nulidade e anulabilidade no direito civil contemporâneo. São Paulo: Almedina, 2017.

TEPEDINO, Gustavo. A tutela da personalidade no ordenamento civil-constitucional brasileiro. In: TEPEDINO, Gustavo. Temas de direito civil. 3. ed. Rio de Janeiro: Renovar, 2004. p. 25-62.

TEPEDINO, Gustavo. O Código Civil, os chamados microssistemas e a Constituição: premissas para uma reforma legislativa. In: TEPEDINO, Gustavo. Problemas de direito civil-constitucional. Rio de Janeiro: Renovar, 2001. p. 1-16.

TEPEDINO, Gustavo. Premissas metodológicas para a constitucionalização do direito civil. In: TEPEDINO, Gustavo. Temas de direito civil. 4. ed. Rio de Janeiro: Renovar, 2008. p. 1-24.

VICENTE, Dário de Moura. Direito comparado. Coimbra: Almedina, 2017. v. I-II.

Recebido em: 07/05/2019

Aprovado em: 06/08/2019 